Western University

Scholarship@Western

Law Publications

Law School

2005

Testing Theory and Debunking Stereotypes:

Lawyers' Views on the Practice of Law

Margaret Ann Wilkinson

Western University,mawilk@uwo.ca

Christina Walker

Peter Mercer

Follow this and additional works at: https://ir.lib.uwo.ca/lawpub

Part of the Law Commons

Citation of this paper:

Wilkinson, Margaret Ann; Walker, Christina; and Mercer, Peter, "Testing Theory and Debunking Stereotypes: Lawyers' Views on the Practice of Law" (2005). Law Publications. 50.

https://ir.lib.uwo.ca/lawpub/50 


\title{
Testing Theory and Debunking Stereotypes: Lawyers' Views on the Practice of Law
}

\author{
Margaret Ann Wilkinson, Christa Walker, and Peter Mercer ${ }^{1}$
}

\section{Part I: Introduction}

There has been increasing scholarly attention paid to the composition of the legal profession in various jurisdictions. ${ }^{2}$ A number of empirical studies have contributed to an improving understanding of the changing composition of the profession as a whole. It has been demonstrated, for instance, that the proportion of women in the legal profession in North America has been steadily increasing and much important work has looked at the experiences of women in the profession. ${ }^{3}$ Various empirical studies have reported factors that influence the numbers of women in the profession at different stages of legal careers. ${ }^{4}$

In 1996, this journal published a special issue on Legal Ethics. Included in that issue, as well as a rich array of theoretical papers, was one describing an empirical investigation of legal ethics that had created "a unique and exciting database that contains lawyers' actual descriptions of dilemmas they have faced in practice and their analyses and responses to those dilemmas." ${ }^{5}$ This article presents the final fruits of the analysis of that database. ${ }^{6}$ In creating that study, the empirical investigators ${ }^{7}$ sought to provide answers to a number of questions:

1. What issues in the practice of law involve ethical decision-making?

2. To what extent do practitioners turn to the Handbook, ${ }^{8}$ to the Practice Advisory Service, ${ }^{9}$ to senior members of the Bar, or to other sources in solving ethical issues?

3. To what extent do these sources, particularly the Handbook, provide the assistance which practitioners seek in solving ethical dilemmas? To what extent are they perceived to provide solutions? To what extent do they obviate the necessity for ethical decision-making in favour of acceptance of perceived authority?

4. To what extent, if at all, do factors such as age, gender, or the law school alma mater of the lawyer affect his or her perceptions and actions in this area and to what extent, if at all, are factors such as the size of the firm or geographic location important? ${ }^{10}$

5. To what extent, if at all, do corporate counsel represent a unique population in the legal profession in terms of issues or attitudes in the practice of law involving ethical decision-making? ${ }^{11}$

The answer to the second question, demonstrated by this research and more fully set out elsewhere, ${ }^{12}$ is that lawyers rarely turn to the text of their ethical codes to solve problems they perceive in the course of their practices. ${ }^{13}$ The profession's ethical codes are one example of a formal information source, one that is externally 
validated by being made public or official. The finding that lawyers tend not to consult their formal codes of ethics is completely consistent with the further finding in this research that lawyers overwhelmingly tend to turn to informal sources of information in problem solving, rather than formal sources. ${ }^{14}$ The code of ethics is also created outside the lawyer's law firm. Again, lawyers' demonstrated reluctance to use it is consistent with the finding from this research that lawyers consistently prefer to search within the firm for information relevant to their problem-solving, rather than going to sources beyond the firm, although this trend was less demonstrable for lawyers from smaller firms. ${ }^{15}$

Having determined, in answer to the second question posed for this research, that the ethical codes themselves are not widely consulted for decision-making, the research also provides answers to the third question in that, even when consulted, ${ }^{16}$ codes of conduct are not often relied upon for ethical decision-making. ${ }^{17}$ Rather, as discussed by Michael Milde on the basis of the findings from this empirical research, ${ }^{18}$ lawyers appear to be engaged in an Aristotelian approach to solving their dilemmas: looking to the "good" role models they identify amongst those practicing as sources of ethical behaviours. ${ }^{19}$

This research study used analysis of lawyers engaged in problem solving as a lens to focus on professional ethics. The investigative method utilized the anecdote interview, also known as the critical incident methodology, whereby the participating lawyers each selected a recent problem they had encountered in practice and that situation formed the basis for the interview. ${ }^{20}$ This led the researchers to rich, deep data based on the lawyers' own experiences. Moreover, the researchers were also able to demonstrate that the range of problems discussed by the lawyers in the study is representative of problems occurring in the profession as a whole. ${ }^{21}$ The first research question asked what issues in the practice of law involve ethical decision-making. Logically, rich data representative of problem-solving in the profession would contain incidences of ethical decision-making. Identifying such incidences in the data, however, led the researchers to focus on the crux of the second and third research questions, and their focus on sources for problem solving: the question at the end of the third research question: "To what extent do [the lawyers' codes of conduct, practice advisory services, senior members of the Bar, etc.] obviate the necessity for ethical decision-making [by lawyers seeking solutions to problems] in favour of acceptance of perceived authority?"

The logic behind this final element of the third research question is that, insofar as lawyers are acting upon the instructions of a perceived authority, they are not acting as autonomous moral agents and are thus not engaged in ethical decisionmaking. This research has determined that the ethical codes of the profession are not considered by members of the legal profession as either relevant or binding in solving most of their dilemmas - but do lawyers rely on other perceived authorities to obviate the necessity of ethical decision-making? These researchers have previously explored the possibility that the client might be one such authority, recognized by lawyers in such a way as to limit the ethical decision-making required of a lawyer. ${ }^{22}$ 
Earlier preliminary analysis of these data has established a number of things. ${ }^{23}$ First, it established both that the issue of the lawyer's role is directly related to examination of the question of ethical decision-making in the practice of law and that the issue of role is of significant concern to today's practitioners. Second, that lawyers do recognize a model of practice in which all decision-making is abdicated in favour of the client's wishes: a model identified in the literature as the "hired gun" model. A contrasting model, in which the lawyer assumes a greater decisionmaking role, and thus can be more engaged as a moral agent, also is identifiable: this model can be termed the "counselor" model. While these two roles have been identified in literature about the legal profession as mutually exclusive, the preliminary findings from this research suggested that the majority of lawyers recognize a metamorphosis from the role of the lawyer as counselor to the role of the lawyer as hired gun over the course of a single case. Finally, the evidence of the interviews analyzed in the preliminary study of these questions was that, although the role of the lawyer is a matter described and delineated in the code of conduct, the issue of role is one determined by lawyers through factors other than either the presentation of models in the legal literature or their ethical codes.

This analytic focus on the role of the lawyer as a vehicle for investigating questions relating to legal ethics has also permitted these researchers to capture evidence on the three themes identified as worthy of empirical exploration when the project was conceived:

I. to explore "whether in fact gulfs now exist between the norms of professionalism and the new realities of daily practice", ${ }^{24}$

II. to examine "the goals of the legal community and the individual aspirations of lawyers ... to determine whether conflicts exist; ${ }^{25}$

III. to examine "the evolving nature of the solicitor/client relationship and the legal profession's obligations to society", ${ }^{26}$

The preliminary study of the data involving role in this research establishes that there is apparently a tension for a significant proportion of lawyers ${ }^{27}$ around the nature of the solicitor/client relationship. In this context, the "goals of the legal profession" and the "legal profession's obligations to society" may be taken to be represented by the Code of Professional Conduct. ${ }^{28}$ While in Ontario the legal profession has undertaken and represented the role of the Ontario lawyer in relation to clients to be one following along a continuum from counselor to hired gun, according to the progression of the file, or case, ${ }^{29}$ even the preliminary analysis of the data from this study establishes that not every Ontario lawyer follows the prescribed role path with every client — and, even in cases where the lawyer's conduct mirrors the prescribed path, the lawyer can experience internal conflict and stress as a result. ${ }^{30}$

The fourth research question asks whether factors such as gender ${ }^{31}$ affect the lawyer's actions in the area of ethical decision-making or whether the size of the firm in which the lawyer practices or the size of the centre in which the lawyer practices makes any difference. The previous analyses of the data have established that the gender of the lawyer plays no part in how lawyers search for information in solving their problems, ${ }^{32}$ nor in whether or not lawyers consult or rely upon their 
codes of professional conduct in solving problems. ${ }^{33}$ Nor does the size of centre in which the lawyer works play any part in how lawyers search for information in solving their problems ${ }^{34}$ or whether or not they consult the code of professional conduct. $^{35}$

The size of the firm in which the lawyer practices, however, was found to influence the extent to which lawyers prefer internal sources of information in problemsolving, with lawyers in smaller firms being more often inclined to seek external sources, while still preferring internal, than those in larger firms ${ }^{36}$ This finding of predominant preference for internal sources is consistent with the relatively scant use of the code of conduct by practitioners found, since, as mentioned above, the code is a source external to the firm. ${ }^{37}$

Moreover, the fact that the use of the Handbook did not vary by firm size is consistent with the finding that the size of firm did not influence whether lawyers preferred formal or informal sources of information: all the lawyers preferred informal sources of information - and, again, the Handbook being a formal source, ${ }^{38}$ it is consistent that so few lawyers appear to use the Handbook in problem solving. ${ }^{39}$

It thus remains in this article to establish three conclusions to the research questions posed at the outset of this project:

(a) Related to the third research question, do the conclusions regarding the attitudes of lawyers towards their roles established in the earlier preliminary study of the attitudes of the lawyers from outside the Metropolitan area also hold true for those lawyers in private practice inside the Metropolitan area and those lawyers practicing as corporate counsel $?^{40}$ Does the evidence of practice across the province in the full study confirm the preoccupation of lawyers in private practice outside the Metropolitan centre with the appropriate nature of the solicitor/client relationship, the gap between the model segue from counselor to hired gun in the Rules of Professional Conduct (the governing statement of the legal profession in Ontario) and the individual aspirations of lawyers and actual practice of law that was found in the preliminary analysis of this evidence?

(b) Related to the fourth research question, while it has been established in this research that only the size of the centre in which the lawyer works has a significant effect upon the sources of information that lawyers use in problemsolving, is gender nevertheless a significant variable in the way in which lawyers approach their roles?

(c) And finally, from the fifth research question: to what extent, if at all, do corporate counsel represent a unique population in the legal profession ${ }^{41}$ in terms of issues or attitudes in the practice of law involving their roles?

The answers to these latter two questions are important, however, not so much because they provide documentation or analysis of possible changes in the structure of the profession but rather because of what they may tell us about whether the emerging structure of the profession is fundamentally altering the practice of law. Having demonstrated that lawyers' views about the proper role of the lawyer may be classified as exemplifying one or other of two classic approaches to the practice of law articulated in the literature on legal professionalism (the lawyer as mentor 
or the lawyer as hired gun), ${ }^{42}$ in this article, these two roles will be identified with two models of ethical decision-making that have been developed in the study of moral development: the mentoring model of a lawyer's role is identified in this article with the care perspective and the hired gun model is identified with the rights perspective. The authors then draw upon the evidence of their large study of Ontario lawyers to discuss these models in light of several aspects of the emerging profile of the legal profession. Finally, the article concludes with an exploration of various explanations for the differences between the attitudes of lawyers that are documented in this study.

\section{Part II: The Empirical Evidence}

As mentioned above, this article is the final report of a research investigation based upon data obtained through a project entitled Professionalism or Profit: The Changing Nature of Legal Ethics. ${ }^{43}$ One hundred and eighty lawyers in large, medium-sized and smaller firms or offices ${ }^{44}$ as well as sole practitioners, at four different-sized centres in Ontario, ${ }^{45}$ were approached and asked to participate in an interview. During the interview, each lawyer was asked to describe a recent incident of decision-making, involving any aspect of law practice, which she or he had found to be difficult. The subsequent interview focused on probing and amplifying the lawyer's account of that incident. One hundred and fifty-four of those lawyers interviewed (86\%) consented to the use of their transcripts in the study. Of these lawyers whose transcripts were included in analysis, 129 were lawyers in private practice and 25 were corporate counsel. ${ }^{46}$

Although the sample of lawyers interviewed was not deliberately created to be proportional according to gender in any way, interviews from women practitioners represented $27 \%$ of those analyzed in the study and this corresponds directly to the overall proportion of women practitioners in Ontario in the years surrounding the data gathering for this study: in 1990 the percentage of women practitioners was found to be $23 \%$ and in 1996 women were $29 \% .{ }^{47}$

This study proceeded from the qualitative evidence provided through this openended interview process. ${ }^{48}$ The transcripts were analyzed and coded for patterns and constructs. ${ }^{49}$ Forty-nine (32\%) of the 154 participants whose interviews were analyzed for the study raised the issue of their roles as lawyers in discussing their problems in practice. ${ }^{50}$ The issue was also raised by just over a quarter $(27.9 \%$ or 36 of 129) of the private practitioners in the study. See Table A. On the other hand, just over half (52\% or 13 of 25 ) of the corporate counsel involved in the study raised the issue of roles. This is a statistically significant difference demonstrating that more corporate counsel than might randomly be expected are concerned about their roles, whereas fewer lawyers in private practice raised the issue. See again Table A. 
Table A:

Chi-square for Role \& Location

(inside Toronto and outside Toronto collapsed to "Private")

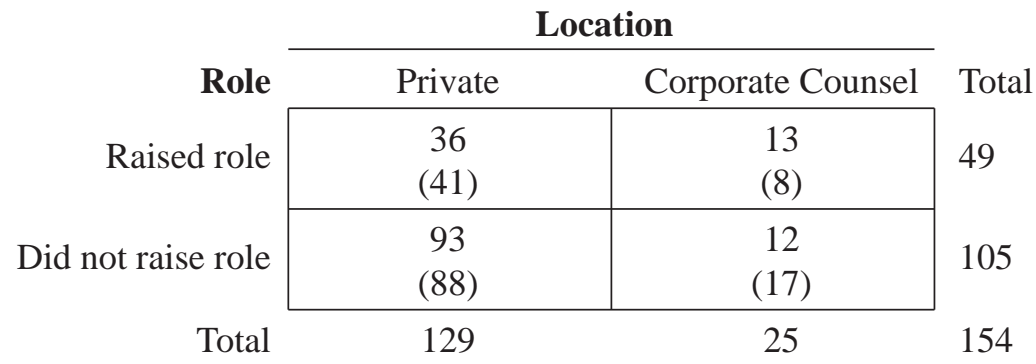

Chi-square $=5.603$

degrees of freedom $=1$

$\mathrm{p}=0.018$ (therefore significant at $0.05 \%)$

(numbers in parentheses indicate expected values)

While fewer lawyers of all those in the study carrying on private practice raised the issue of role when compared with the corporate counsel, further analysis demonstrates that it is private practitioners in the largest metropolitan centre who raised the issue fewer times than expected: those in Ontario centres smaller than the Metropolitan centre ${ }^{51}$ raised the issue as often as might be expected. See Table B.

\section{Table B:}

\section{Chi-square for Role \& Location}

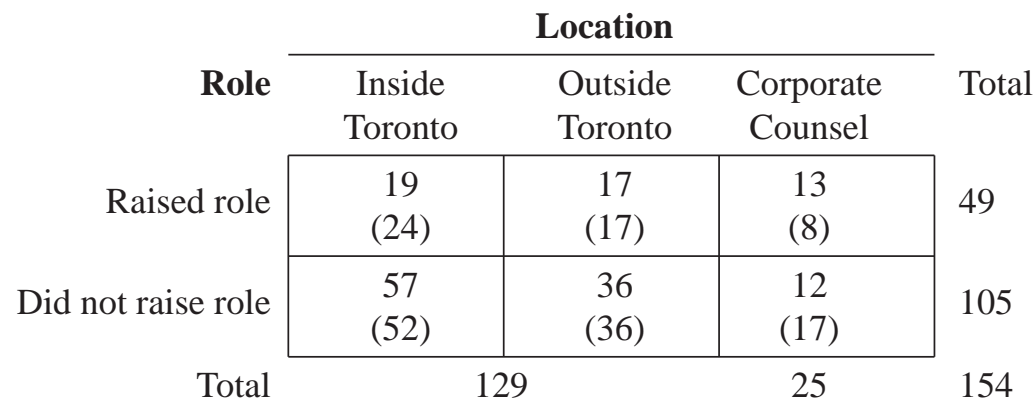

Chi-square $=6.324$

degrees of freedom $=2$

$\mathrm{p}=0.042$ (therefore significant at $0.05 \%$ )

(numbers in parentheses indicate expected values)

Table $\mathrm{C}$ reports the data from the study that of the forty-nine lawyers who raised the issue of role in this study of 154 Ontario lawyers, it was the case that the issue 
of their role was raised by 38 male lawyers and 11 female. Proportionately, however, there was no significant difference between the number of male and the number of female lawyers in the study who raised the issue of role during their interviews. ${ }^{52}$ The cell sizes in Table $\mathrm{C}$ make it impossible to determine whether the apparent differences between the numbers of men and women who raised role in Toronto, outside Toronto, or as corporate counsel are real differences or are merely random effects of the sampling in this study. ${ }^{53}$

\section{Table C:}

\section{Distribution by Sex and Location of Only Those Who Raised Role}

\begin{tabular}{|c|c|c|c|}
\hline \multirow[b]{2}{*}{ Location } & \multicolumn{2}{|c|}{ Sex } & \multirow[b]{2}{*}{ Total } \\
\hline & Male & Female & \\
\hline Inside Toronto & 18 & 1 & 19 \\
\hline Outside Toronto & 11 & 6 & 17 \\
\hline Corporate Counsel & 9 & 4 & 13 \\
\hline Total & 38 & 11 & 49 \\
\hline
\end{tabular}

Literature previous to this research project had suggested that the researchers would find a dichotomy between those lawyers who saw themselves as hired guns, strictly representing the views of their clients in the appropriate forums, and those who saw themselves as mentors, guiding their clients to appropriate positions on legal issues. ${ }^{54}$

The early analysis of the sub-set of the interview transcripts from outside Toronto created in this study ${ }^{55}$ confirmed that one of these two distinct approaches concerning the lawyer's role had been taken at any given time by each of those lawyers in this study.

\section{Part III: The Background Context}

\section{A. The Theory of Moral Development}

For years, the dominant literature of moral development followed Lawrence Kohlberg, whose theory was based solely on the response of 75 males. ${ }^{56}$ However, in the 1970's and 1980's, several theorists began to challenge the existing models, suggesting that moral development may differ in males and females. One of Kohlberg's most vocal critics was Carol Gilligan, his former student, who argued that his model was based on male development, not human development. In 1982, Gilligan published a book entitled In A Different Voice: Psychological Theory and Women's Development, in which she suggests that men and women have different moral perspectives. ${ }^{57}$ According to Gilligan, morality can be approached from two different perspectives. One perspective, which Gilligan characterizes as the care perspective (also called the ethic of care), views human interactions as a web of 
interdependent relationships. Persons with this perspective view themselves as being connected and interdependent on others. These persons focus on the outcome of decisions - how actions will harm others, how seriously, and in what way the relationships with others will be affected. The other perspective, one Gilligan characterizes as the rights perspective (also called the ethic of rights), views human interactions as a set of contractual relations. These persons separate themselves from others and preserve relationships through a fair resolution of conflicts. What is fair is fair as determined by rights, duties and appropriate rules.

Based on her empirical observations, Gilligan concludes that women most often resolve dilemmas from the care perspective, while men resolve issues from the rights perspective.

Gilligan's theory, that there are these two different moral perspectives and that one can be identified more closely with each gender, has not been accepted by all..$^{58}$ Gilligan has received criticism for the methodology used in her studies. ${ }^{59}$ Even accepting her methodology, she has been criticized for assuming that the differences she has found empirically are the result of gender, rather than owing to other factors. ${ }^{60}$ Gilligan has also faced criticism for presuming that her theory applies to all women, regardless of social class, race, religion and ethnic group. ${ }^{61}$

Despite the criticism her theory has received, Gilligan continues to use gender as a separate experimental category ${ }^{62}$ and remains very prominent in the area. ${ }^{63}$ The question of whether or not gender is a factor in how people think and act remains ambiguous, as subsequent studies have both supported ${ }^{64}$ and refuted ${ }^{65}$ her theory.

Although this study did not employ an experimental methodology which predetermined an examination comparing the rights and care perspectives among lawyers, previous analysis of the views of lawyers conducted as part of this research has established that lawyers' views of their roles may be characterized as either a hired gun or a mentor model. ${ }^{6}$ A review of the characteristics of the mentor and mercenary (or hired gun) models taken from the literature of legal professionalism demonstrates that lawyers who adopt the mentor role may also be taken to be working from the care perspective identified in the work of Gilligan and others, while those lawyers who adopt the hired gun role may be said to be working from the rights perspective.

In adopting the mentoring role, the lawyer must weigh competing and concurrent third party interests, as well as those of the client, in order to decide how to advise the client. The lawyer must consequently thoroughly weigh all available options and encourage the client to be thoughtful in making the ultimate decision. ${ }^{67}$ This involves the lawyer in responding to the actual individual needs and circumstances of the client, whether or not those needs are articulated by the client. This emphasis upon the interdependent relationships involved in the client's situation and the multiple impacts possible from any particular client choice identify this role as one essentially involving the care perspective.

From the hired gun, or mercenary, perspective, the lawyer is to act strictly as the agent of the client. The role of the lawyer is exclusively to pursue the goals identified by the client and follow the clients' instructions explicitly. The lawyer adopting this model of her or his role is under no duty to be certain that the client 
is acting reasonably in a given situation, but rather is under a duty only to ensure that, insofar as the lawyer is acting for the client, her or his actions remain within the bounds prescribed by law. ${ }^{68}$ This conception of the lawyer's role naturally involves a perception of the interaction of the lawyer and client based upon a contractual relationship. The adoption of this role permits a lawyer to maintain a perspective separate from that of the client - to view the consequences of the client's choices as consequences flowing from the system of law and justice. This is consistent with the rights perspective. One of the themes of this article will therefore be to establish the relationship between the hired gun role or rights perspective and the mentor role or care perspective for private practitioners in both large and small centres as well as for corporate counsel. A second theme of this enquiry will be to establish whether the distinction between the two roles or perspectives is gender-linked.

\section{B. Gender and the Practice of Law}

It has been predicted that there will be far-reaching social consequences in creating a greater female presence in the legal profession. It has been suggested, for example, that the presence of women may change the adversarial nature of the system, by countering the adversarial process with a co-operative, non-adversarial approach more attuned to women's central concern with maintaining relationships. ${ }^{69}$ It is difficult to discern empirically whether such shifts in the practice of law are occurring. This study contributes to that process of discernment by testing, in reports of the actual practice of law, predictions that arise from Gilligan's particular theoretical perspective derived from empirical work in other contexts.

As one student of the law has said, "It seems that [Gilligan's theory of] the different voice answers the question: What difference will women [in the legal profession] make?"70 If Gilligan's theory that women most often resolve dilemmas from a care perspective proves true for the practice of law, then the increased presence of women in the field can be expected to have profound social consequences on the justice system in our society.

Proponents of this thesis conjecture that, by bringing the perspective dominant within their gender to the legal profession, the increasing presence of women in the profession will transform the very foundations of the legal system so that it will demonstrate more concern for the needs of each unique person and a growing emphasis on building and strengthening the relationships among individuals ... informed by the ethic of care, the law could become less individualistic and more communitarian in its focus. ${ }^{71}$ This position is consistent, for example, with the argument made by Shaughnessy that "throughout the nineteenth and twentieth centuries, many feminists have embraced, rather than rejected, gender differences. Women have argued that their concern for human life, their purity and their moral sensitivity equipped them to make a special contribution to public life." 72

To date, three studies have specifically attempted to predict whether this gendered distinction between the care and the rights perspectives can be detected in the practice of law. ${ }^{73}$ 
The first study was conducted in the 1980's by Rand Jack and Dana Crowley Jack, who interviewed 36 lawyers (18 male, 18 female) from a county in Washington. ${ }^{74}$ In each interview, the lawyer was questioned about (1) her or his general moral orientation, (2) her or his real life dilemmas, and (3) how she or he would resolve two hypothetical dilemmas. In each of these three categories, the researchers found that a majority of the women adopted the care perspective when responding, while a majority of the men adopted the rights perspective. ${ }^{75}$

However, in looking at the response to a real life dilemma of one of the participants, there was a shift in his perspective when his client was less fortunate and needed special attention. The participant went from a strong rights perspective to a care perspective. The language used to describe the client's needs was rights oriented, while the resolution sought fitted in with a care perspective. ${ }^{76}$ No shifts in perspective-taking were seen when participants answered the hypothetical dilemmas presented. ${ }^{77}$

A later study, involving seventy second-year law students in her income taxation class, was conducted by Nina Crimm in $1994 .{ }^{78}$ One aspect of the study was to determine whether the students, as prospective lawyers, had any automatic tendencies to incorporate either the morality of rights or the morality of care perspectives in their legal argumentation, and, if so, whether their choice of one or the other followed gender lines. She also designed the study to include a component in which the students attempted to provide proxy evidence to approximate the decision-making behaviour of judges. Data for both parts of the study were obtained from the final examination in the income tax course through the analysis of the answers to an essay question involving a moral dilemma presented in the context of a hypothetical tax case. The results of the study indicated that there were no significant differences between male and female tendencies to use the care or rights perspectives. $^{79}$

Most recently, Carla Hotel and Joan Brockman have conducted a study of 36 lawyers who predominantly practiced family law in Vancouver, British Columbia, and the surrounding Lower Mainland area ${ }^{80}$ Each lawyer in the study was presented with a hypothetical situation designed to involve her or him in a discussion about how she or he would deal with a client whose instructions were to proceed in a manner that was not in the best interests of the child involved in the scenario. Consistent with the findings of Jack and Jack mentioned above, Hotel and Brockman found that a majority of the women responded from the care perspective while a majority of the men responded from the rights perspective. ${ }^{81}$

Two of the above studies provide some support for the prediction that men and women differ in their roles as lawyers although in both cases the lawyers' responses were based on hypothetical situations. The one study that looked at lawyers' real life dilemmas found that most of the lawyers interviewed possessed aspects of both the care and the rights perspective, and that real life situations produce different results than do hypothetical dilemmas. ${ }^{82}$ Therefore, whether male or female lawyers respond from the rights or care perspectives in practice has not been established. ${ }^{83}$

This present study examines evidence taken from lawyers' reports of their actual experience of the practice of law and therefore can shed light upon the question 
of whether gender actually appears to influence the choice of a practitioners' perspective (rights or care) on the role of the lawyer in the practice of law.

The work of Gilligan and others, and the results of two of the three studies in law discussed above, would suggest that the male lawyers in this study should show a preference for adoption of the hired gun or rights perspective model of the role of the lawyer, while female lawyers should predominately demonstrate a care perspective through adoption of the mentoring or counseling model. Further, it would be expected, based on these other studies, that more women lawyers than men who reported having experienced conflict with their clients would have maintained a counseling and mentoring attitude toward their clients. On the other hand, men who had initially adopted a counseling model might be expected, when faced with a conflict with the client, to make the transition to the hired gun role smoothly, rather than either trying to stay with the counseling model or internalizing stress when adopting a hired gun role. The women who had begun with a counseling model and then moved to a hired gun role, on the other hand, again based on these earlier studies, would be expected to exhibit signs of stress.

\section{Practicing In-house versus Private Practice}

As mentioned, one criticism of Gilligan's work is that she focuses solely on gender as the explanation for differences in perspective that she documents. In addition to an examination of possible gender differences in determining lawyers' attitudes toward decision-making, this research will also look at two structural variables. The first is the type of practice in which the lawyers are engaged. ${ }^{84}$

The perceived role of the corporate lawyer has changed over time-but has been seen to be different from the role of the private practitioner. ${ }^{85}$ At the early inception of the corporate-based practice, counsel focused on the needs of large companies held a prestigious position. ${ }^{86}$ However, "[u]nlike accountants, who have been both more integrated into companies and more mobile on its corporate ladders, in-house lawyers are a relatively new development..." ${ }^{87}$ Post World War I, in-house or corporate lawyers, had come to be referred to as "kept lawyers", ${ }^{88}$ symbolizing the perception of them as more dependent on their clients, who are in fact also their sole employers, than is the case for those lawyers in private practice. With the development of the Masters of Business Administration and other business programs, a business background became an increasingly desired attribute for success within the corporate hierarchy. With the advent of this new breed of corporate executives, the in-house lawyer's status was perceived as declining ${ }^{89}$ With that decline in status, the compensation for the work also diminished. ${ }^{90}$ As a result, the corporate legal department came to be viewed as the refuge for lawyers who did not succeed at law firms. " "Rightly or wrongly, corporate counsel have been seen by many law firms as second-tier in-house legal advisors, good enough for the daily grind, but not the big deals." 92

In even more recent years, there has been steady change toward yet another definition of in-house counsel. These lawyers are seen as an integral part of the running 
of the corporation - “redefining their role within Corporate Canada's power structure and transforming the role of law departments from a support or service role to that of a strategic business advisor ... from pure service provider-on par with other central service departments such as human resources, accounting and IT-to an integral and respected part of the management team. ${ }^{93}$ No longer do they do only the simple legal tasks, rather they pick and choose the most interesting aspects of the work available and hire outside law firms to pick up the overflow. The new in-house counsel thus manage the company's involvement with outside legal counsel. Furthermore, emphasis is also placed on preventive law practices. This means that the in-house counsel is involved in the development of corporate planning and goals and advises on legally sound approaches to achieving these goals. In-house lawyers are also expected to use their legal expertise to predict possible future legal trends in corporate regulation and how these trends will affect their client corporation. The corporate counsel solving these current and anticipated legal problems is to keep in mind the corporate goals and present solutions that are consistent with both the dictates of the law and the needs of the company. The overall role of the emerging corporate lawyer is to manage the legal aspects of corporate life on a day-to-day basis, not merely from a legal perspective but also from a more global approach, integrating all they know about the corporation and its goals into the process. ${ }^{94}$

The unique role played by in-house corporate counsel has led to different evaluations of the professionalism of these lawyers. On one view, a negative inference can be drawn from the fact that there is seen to be the possibility of a blurring between the actions of the client and its corporate counsel. Such a blurring, it is argued, cannot occur in the relationship between private practitioner and client, because, while the private practitioner only arrives on the scene after the legally questionable incident occurs, the corporate counsel is privy to its development. ${ }^{95}$ On the other hand, a more positive spin is placed upon the relationship by the "Inside Counsel Movement," 96 in particular, which distinguishes the service provided by the corporate counsel as being more ethical than that provided by lawyers in private practice, ${ }^{97}$ in that such service takes into consideration all of the client's needs and plots a course of action that is in the best interest of the client. ${ }^{98}$ On this view, counsel in private practice look primarily at resolving the legal question, not necessarily considering the corporation's other goals and how the legal solution affects those goals. Both critiques reflect a critical evaluation of responses by corporate counsel to a role that is essentially perceived as the same, despite the differing critiques: the role of the corporate counsel identified in both critiques is essentially that of the mentor, reflecting the care perspective. By contrast, the private counsel role reflected in both of these two critiques of the corporate counsel's role seems to postulate the hired gun, rights perspective.

It might be thought that in-house counsel would have a longer-term perspective in helping and guiding their clients since they will remain at their companies after any specific lawsuit is over. If the results of particular legal advice are detrimental to the company, these in-house counsels will have to deal with the fall-out on a day to day basis for some time to come. If an in-house counsel becomes unpopular, 
he or she may lose not only client but also job. Outside counsel, it might be thought, do not have the same degree of involvement with their clients. If the legal results are not optimal for all aspects of the client company's goals, there is a very real caveat on the private counsel's work - that she or he did not know the inside workings of the client company and, beyond following the client's instructions on the specific legal situations involved, could not know the wider context within the client company. As well, private "outside" counsel have other clients and are not working on site. Thus private counsel will suffer less serious overall repercussions if not all of a particular client's goals and expectations are met. The very purpose of an in-house corporate practice is to provide ongoing guidance and specifically to take into account the corporate goals when solving a legal problem, to a greater extent than a hired private counsel would.

Since the rights perspective is characterized by rights, duties and appropriate rules and since corporate counsel are hypothesized to be more care oriented, it was also postulated that they would be less likely than private counsel to cite the Code of Professional Conduct and would be less satisfied to accept and apply its dictates.

Thus, given the literature and the unique position of corporate counsel, in this present analysis corporate lawyers were expected to show more of a care perspective than private lawyers. Moreover, the expectation that corporate lawyers would take a care perspective in their role led to the expectation in this study that the corporate lawyers would experience a significant level of distress if they were not able to maintain that role and were forced to act the part of the hired gun. Conversely, for private practitioners, who are hired when a client's problem arises, the concept of a hired gun would not appear to be as incongruous with their self-perceptions as it would with those of the corporate counsel, and thus, in this study, private counsel were expected to exhibit a rights perspective on their roles. Moreover, the level of distress experienced by the private practitioners when they are forced to take on the hired gun perspective was expected to be lower than in the case of the corporate counsel.

\section{Small Town Practice and Big City Practice}

The second and final structural factor that the researchers in this study thought could influence the role of the lawyer was the size of the centre in which the practice was located. The sampling method used in the research was designed to provide as geographically representative a picture of practitioners throughout the province as possible. Ontario's urban centres were classified into four groups based on population:

- Metropolitan centre:

- Large urban centres: $100,000-499,999+$

- Medium urban centres: 10,000 - 99,999

- Small urban centres: $\quad 1,000-9,999$

Interviews were conducted in four geographically diverse locations: one metropolitan region, one large urban centre, and two medium urban centres. ${ }^{99}$ 


\section{Part IV: Findings}

\section{A. The Role of the Lawyer}

Every one of the 49 Ontario lawyers in this study who discussed the role of the lawyer in connection with her or his problem in practice described her or his starting relationship with the client involved in the problem in language which identified the relationship as a mentoring or counseling one. See Table D, first 3 rows. ${ }^{100}$

Table D:

\begin{tabular}{|c|c|c|c|c|c|}
\hline & & \multicolumn{2}{|c|}{ Private practice $^{3}$} & \multirow[b]{2}{*}{$\begin{array}{c}\text { Corporate } \\
\text { counsel }^{4} \\
\mathrm{~N}=25\end{array}$} & \multirow[b]{2}{*}{$\begin{array}{c}\text { Total }^{5} \\
\mathrm{~N}=154\end{array}$} \\
\hline & & $\begin{array}{l}\text { Outside } \\
\text { Toronto }^{1} \\
\mathrm{~N}=53\end{array}$ & $\begin{array}{c}\text { Inside } \\
\text { Toronto }^{2} \\
\mathrm{~N}=76\end{array}$ & & \\
\hline 1 & Total transcripts involving role & $17(32 \%)^{a}$ & $19(25 \%)^{\mathrm{a}}$ & $13(52 \%)^{\mathrm{a}}$ & $49(32 \%)^{\mathrm{a}}$ \\
\hline 2 & Hired gun role embraced & 0 & 0 & 0 & 0 \\
\hline 3 & Counsellor role embraced & $17(100 \%)$ & $19(100 \%)$ & $13(100 \%)$ & $49(100 \%)$ \\
\hline 4 & $\begin{array}{l}\text { No conflict with client } \\
\text { (moved to ultimately agree } \\
\text { with lawyer's counseling) }\end{array}$ & $5(29 \%)$ & $9(47 \%)$ & $6(46 \%)$ & $20(41 \%)$ \\
\hline 5 & Conflict with client & $12(71 \%)$ & $10(53 \%)$ & $7(54 \%)$ & $29(59 \%)$ \\
\hline 6 & $\begin{array}{l}\text { Lawyer didn't substitute own } \\
\text { judgment for client's decision }\end{array}$ & $12(71 \%)$ & $8(42 \%)$ & $5(38 \%)$ & $25(51 \%)$ \\
\hline 7 & $\begin{array}{l}\text { Lawyer substituted own } \\
\text { judgment for that of client }\end{array}$ & 0 & $2(5 \%)$ & $2(15 \%)$ & $4(6 \%)$ \\
\hline 8 & Lawyer withdrew from case & $5(29 \%)$ & $2(11 \%)$ & $0(0 \%)$ & $7(14 \%)$ \\
\hline 9 & $\begin{array}{l}\text { Lawyer didn't withdraw from } \\
\text { case (moved to hired gun role) }\end{array}$ & $7(41 \%)$ & $6(32 \%)$ & $5(38 \%)$ & $18(37 \%)$ \\
\hline 10 & $\begin{array}{l}\text { Lawyer ultimately agreed with } \\
\text { client's view (No stress) }\end{array}$ & $7(41 \%)$ & $10(53 \%)$ & $6(46 \%)$ & $23(47 \%)$ \\
\hline 11 & $\begin{array}{l}\text { Lawyer didn't agree with } \\
\text { client's view }\end{array}$ & $5(29 \%)$ & $5(26 \%)$ & $5(38 \%)$ & $15(31 \%)$ \\
\hline 12 & $\begin{array}{l}\text { No evidence of internal } \\
\text { conflict and stress }\end{array}$ & $4(24 \%)$ & 0 & $1(8 \%)$ & $5(10 \%)$ \\
\hline 13 & $\begin{array}{l}\text { Evidence of internal conflict } \\
\text { and stress }\end{array}$ & $1(6 \%)$ & $5(26 \%)$ & $4(31 \%)$ & $10(20 \%)$ \\
\hline
\end{tabular}

All percentages are calculated of the "total transcripts involving role" (top row of table), except the percentages in that row itself. See note ${ }^{a}$.

a These percentages are calculated of that category's total transcripts ( $\mathrm{N}$ value).

${ }^{1}$ see Figure 1

${ }^{2}$ see Figure 2

${ }^{3}$ see Figure 3

${ }^{4}$ see Figure 4

${ }^{5}$ see Figure 5 
Figure 1 illustrates the roles adopted throughout the problems they discussed by the lawyers in private practice in the centres smaller than Toronto. ${ }^{101}$ The larger typeface numbers shown on Figure 1 correspond with the numbers appearing in the "Outside Toronto" column of Table D. The smaller numbers in parentheses in Figure 1 indicate the breakdown by gender of each set of lawyers at each point in this "tree" diagram.

Figure 2 illustrates the roles adopted by the lawyers in private practice in the largest centre studied, identified in Table D under the column marked "Inside Toronto".

The private practitioners from all sizes of centre are represented in Figure 3, combining the results shown in Figure 1 with those shown in Figure 2.

Figure 4 describes the roles adopted by the corporate counsel studied. The corresponding column of Table D is, indeed, labelled "Corporate counsel".

Finally, Figure 5 depicts the roles described by all the lawyers in the study who discussed role, thus corresponding to the column in Table D marked "Total".

The fact, mentioned above, that none of the lawyers studied initially adopted a hired gun approach to their roles is illustrated by the fact that the second row of Table D has only 0 values in all the columns and by the fact that the top left corner position in all five of Figures, labelled "Hired Gun Role embraced", shows a 0. One example of the mentoring role being adopted is the following:

The very difficult situation was to spend literally hours with the birth mother trying to assist her with coming to terms with the court application for Crown Wardship and adoption. And, bring her to the point where she, of her own volition, would recognize that it was in the best interests of the child that [it] not be placed with her, which was her original request, to defeat the Children's Aid Society application, but rather to allow for an order, agree for an order of Crown Wardship ..., at which time the child would be placed with the foster parents.... There were a lot of tears and a lot of agony. The process was extremely difficult. ...

Interviewer: And you felt it was in the best interest of the child to go to the foster home

I felt it was, but I have to be guided by my client's instructions... and I certainly could not suggest that this was what should happen if she did not agree... So we had some counseling outside. We went to [city] together, she and I, to discuss and meet with doctors who had cared for [it] when [it] was born, to address the physical needs [it] would have. In an attempt to determine whether she could meet those needs

Interviewer: That was all on your investigating?

Yes. So eventually the order was made. ... To process of getting from... my client having been served with documentation to take away her child and her adamant opposition to that, to help her come around. I did not tell her what she was going to do, she decided what she was going to do but it was a hard process.

Interviewer: ... was ... your stance that it would be in the best interest of the child?

That is not my determination to make in a situation like this.... Because she is my client and I act on her instructions. But what I have to present to her is a range of options.... it is very hard and until you have seen someone cry to the point where their whole body shakes, their whole being, you think they will be torn apart, and you know the pain. You can't ignore that, that's part of what you do. When you are 
a family lawyer, you are a counselor, you are a social worker, to a very limited extent you are a financial advisor, you know, in terms of what people can do and can't do. ${ }^{102}$

Having all embraced an initial counseling role, ${ }^{103}$ twelve $(71 \%)$ of the counsel outside Toronto experienced resulting conflict with their clients (see the 5th row of Table $\mathrm{D}^{104}$ ), whereas a much smaller percentage of both private practitioners inside Toronto (ten, or 53\%) and corporate counsel (seven, or 54\%) experienced conflict with the client at this point.

Finding themselves in conflict with their clients, none of the private practitioners from outside Toronto substituted their own judgment for that of their client (see the 7 th row of Table $\mathrm{D}^{105}$ ) whereas two of the lawyers in private practice in Toronto did this and two of the corporate counsel. This action effectively took these four lawyers out of the role of counsel and into the role of surrogate for their clients. Such a situation was described by one of the corporate counsel as follows:

...the tenant indicated that they would, not to us directly but through the mall management, that they would be emptying inventory from the store. And it was after six o'clock in the evening and I was still here, myself and one other person. And they actually started to empty the store. But I had to make this decision, and we chose to go in and change the locks... I told him to change the locks and secure the guards. ... I would normally in a situation like that actually rely on what we call a "business person" here, to make those types of ultimate calls. But every once in a while, I get to do them myself. That's the situation.

Interviewer: Now did you feel that you had the authority to make this decision?

Uh, Yes. I didn't feel it in my capacity as a lawyer, but then my job here is much grayer than just being a lawyer. I've been given a certain level of position where they expect me to make certain business decisions. And that's a hard thing to learn as a lawyer, because lawyers don't make business decisions-lawyers give advice and let others make decisions. I specifically had been given a middle role. And I'm considered management, and I'm supposed to make certain decisions. In my capacity as a lawyer, I still try to give all the advice and get all the input from what I call the business people and the business units. But ultimately, I am given the authority and the responsibility to make some decisions, actually quite a few on my own. ... normally in a corporate counsel position you would get a vice-president or somebody else to make that final decision as to whether to change the locks or whether to take the risk to go in and seize the goods, which may be slightly illegal. I don't necessarily get that here. I sometimes make those decisions. And it's acceptable for my company, I don't know if it would be considered acceptable from a legal sort of standpoint or Law Society standpoint. My job is gray in that area. ${ }^{106}$

In all the cases of conflict but these four, where the lawyers remained in the role of counsel, the lawyers either left the case or embraced the client's instructions and thus took on the hired gun role. As might be expected from the nature of their position, no corporate counsel were found who had left the case when a conflict arose with the client (see Table D, 8th row $^{107}$ ). In the position of corporate counsel, as an employee, withdrawing from the case would probably have involved leaving their employment, although no corporate counsel interviewed mentioned this possibility in any aspect of their interview. ${ }^{108}$ On the other hand, in two cases involving private practitioners in Toronto ( $11 \%$ of the nineteen cases involving role in Toronto) and 
in five cases involving private practitioners in smaller Ontario centres (29\% of the lawyers outside Toronto discussing role), the lawyers withdrew from the case rather than adopted the hired gun role which would have required them to act against their own personal views and act according only to their clients' views. ${ }^{109}$

The lawyers who were in conflict with their clients' views but decided not to withdraw from the case were compelled then to take on the role of the hired gun and take the instructions of their clients even though they disagreed with them. This occurred in 18 cases: five times for corporate counsel (in 38\% of cases), six times for private counsel in Toronto (32\%) and seven times for private practitioners outside $(41 \%)$. See Table D, 9th row. ${ }^{110}$

Moving down the right hand side of Figures 1 to 5, then, it can be seen that both in cases where the lawyers never had any conflict with the client's instructions because the client embraced their counseling from the outset (see the 4th row of Table $\mathrm{D}^{111}$ ) and in cases where the lawyers, after initial conflict with their client's instructions (because the clients did not adopt their counseling), then moved to adopt the client's position and behave as a hired gun, it is the client's view of the matter which prevails. However, while in some cases, despite their initial advice to the contrary, the lawyers came to accept their client's views (see Table D, 10th row), in other cases, the lawyer, while acting according to the client's instructions, nevertheless continued to view the client's instructions as inappropriate in the circumstances (see Table D, 11th row ${ }^{112}$ ). Those who had come to accept their client's views showed no signs of residual internal conflict or stress in their interviews about these situations. The other two groups of lawyers who resolved their conflict with the client and showed no signs of internal conflict or stress at the outcome of their problems were the lawyers who had left their cases and the lawyers who had substituted their own decisions for those of their clients. These lawyers are shown in Figures 1 through 5 at the middle bottom of each "tree" under "No internal conflict or stress" ${ }^{113}$ On the other hand, even where the lawyers did not ever adopt their client's views of the case, relatively few lawyers reported these problems in terms that indicated residual internal conflict or stress: only one lawyer outside Toronto but five (26\%) in Toronto and four (31\%) of the corporate counsel. ${ }^{114}$

Thus, at the end of the day, the clients' view prevailed in terms of the outcome of the case in 38 cases ${ }^{15}$ of the total 49 cases in which role was discussed: ${ }^{116} 11$ times out of 13 for corporate counsel ${ }^{117}$ (where, on the other hand, counsel substituted their own decisions in two cases, but never withdrew $\left.{ }^{118}\right), 15$ times out of 19 for Toronto lawyers ${ }^{119}$ (where, on the other hand, lawyers withdrew in two cases and in two cases the lawyer substituted his or her decision for that of the client ${ }^{120}$ ), and 12 of 17 times for private practitioners in the smaller centres ${ }^{121}$ (where, on the other hand, lawyers never substituted for their clients' decisions but did withdraw from five cases ${ }^{122}$ ).

These results, no corporate counsel withdrawing from any case and the incidences of corporate counsel substituting their own judgment for that of the client, do provide evidence of a difference in attitude between corporate counsel and private practitioners. This difference was clearly articulated by one of the participating corporate counsel: 
Typically when you're an in-house lawyer, you're expected not only to give an opinion and sort of leave it on the shelf, but take the client by the hand and say "well, if you can't do it that way, then understanding how this company does business, then this is the way we can go about it, this is the proper way to deal with these issues." ...To do a job well as an in-house counsel you have to be seen to, while being totally professional and not being dragged into the business side, you have to be seen as a facilitator as well. If you're merely a gate-keeper and you say to someone "no, you can't do that," then you're not performing the function ... I can't speak that well to private practice because I haven't been in private practice for a long time, but I know that what I do I' $m$ expected to exercise the opinion of the lawyer, the judgment of the lawyer, but at the same time facilitate the company doing business. If I merely [give] an opinion, I say “you can't do that," people stop coming to you. So if you're someone who I know ... usually ... consults with me, ... listens to what I say-I can tell him "I think you should do it a certain way" but ultimately the decision will be made by people, not playing the lawyer's role, as to whether or not they take that advice, just the way any lawyer advises a client. But the client doesn't necessarily take your advice. ${ }^{123}$

In these 38 situations where the clients' view prevailed during the cases, the transcripts of the interviews revealed that the lawyers ultimately had differing views about whether the clients' views were correct. Indeed, in many cases, it was these final considerations that led the lawyers involved to raise these particular cases as the ones they wished to discuss with the research interviewers as their problem scenarios:

It involved a decision as to whether or not to follow a client's wishes. And I think a lot of these things [problems in practice], you are going to find out, may involve that kind of thing. ... Because if I am aware of that particular situation [a potential future problem stemming from the client's idea] ... I guess probably one of the most important lessons from that is don't get too involved in getting co-opted by the client. And I had. ... I guess that is about the most difficult decision that I have had to make. ... I guess the other thing it taught me was don't listen to your clients, even though you expect, or you know, or you feel that they know what they are talking about, and you trust them, I think it is almost a maxim that your client can turn out to be your worst enemy if you are not careful. ... What he was asking was something quite legitimate....

Interviewer: So has this changed the way in which you deal with your clients in general?

... I don't do things clients instruct, even though they may sound terribly convincing, and I don't mean that to be as bald a statement as it sounds. If I get instructions from the client to do something that I feel is in their best interest, and it is indeed in their best interest, and there is no question, then I would proceed. If it is iffy, and contrary potentially to the client's best interests, but the client is insistent, then I either tell the client to get other legal representation and decline to act, or I get it in writing if it is something that is possible to live with. ${ }^{124}$

In situations where the lawyers and their clients disagreed but the lawyers ultimately adopted a hired gun approach and acted for the clients, against their own views, the lawyers in private practice outside Toronto seemed to accept the situation with the most equanimity, showing no resultant internal conflict or stress in most such 
cases (4 out of 5). Four of five of the corporate counsel reported ongoing stress, while all of the Toronto counsel reported stress over this role. However, when one looks at the percentages of respondents involved, it is clear that the corporate counsel, in the end, exhibited the highest ongoing stress level with $31 \%$ of respondents indicating internal conflict or stress remaining at the end of the resolution of the cases they described. On the other hand, the most stress-free at the end of the processes described were the private practitioners practicing in the smaller communities outside Toronto (6\%). The private practitioners from within Toronto exhibited the median-point of stressed respondents, but that point (26\%) was closer to the stress levels of the corporate counsel than to the private practitioners outside Toronto. ${ }^{125}$

\section{Figure 1. The Role Taken by Lawyers in Private Practice in Smaller Centres}

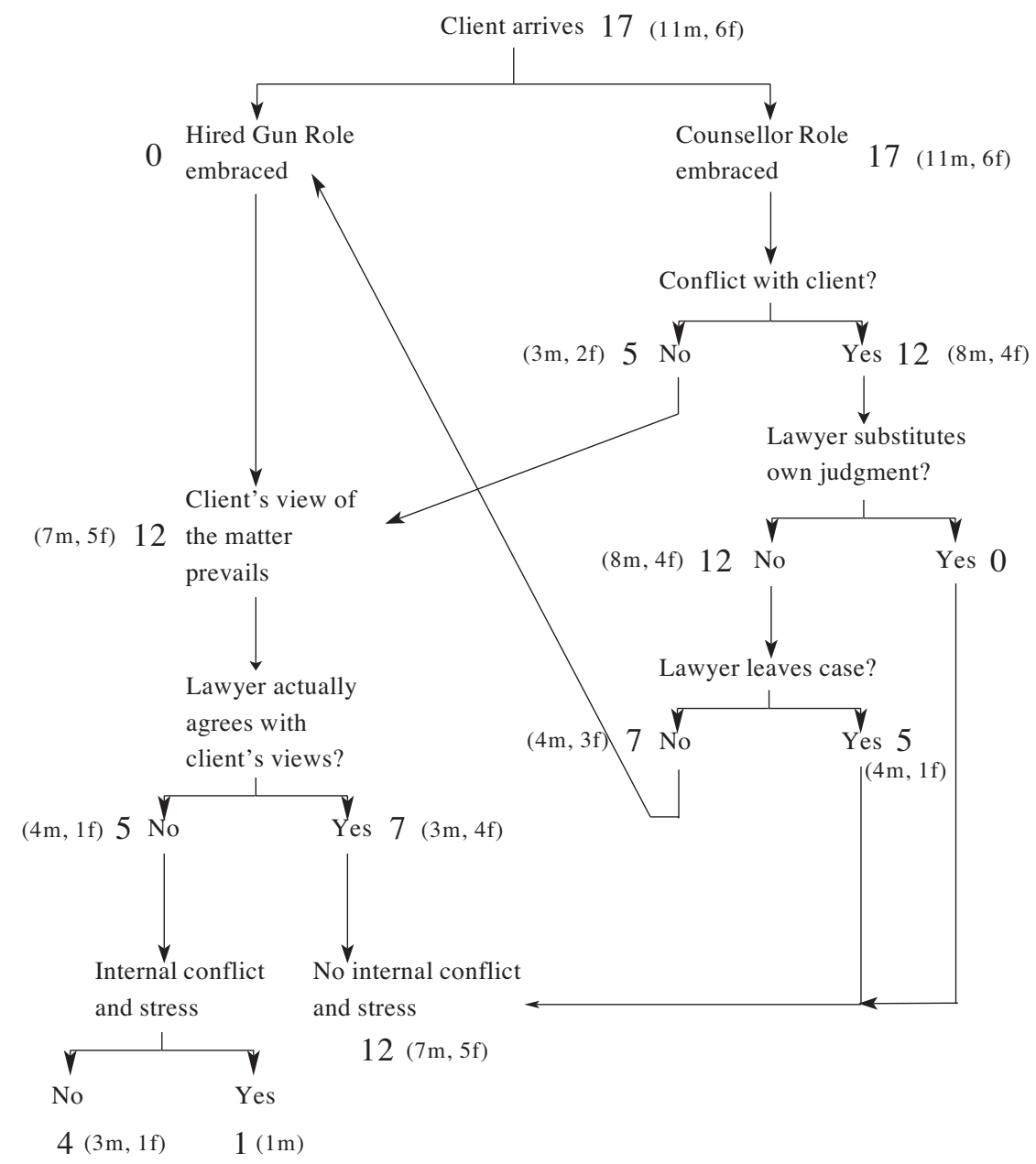


Of those seven lawyers who clung to the counselor role after coming into conflict with the client to the point of actually leaving the case, six were men and only one was a woman. ${ }^{126}$

Of the four lawyers who actually stepped out of the role of lawyer altogether and usurped the decision-making function of the client, two were female corporate counsel (the only two who chose, as corporate counsel, to substitute their judgments for those of their clients ${ }^{127}$ ). Indeed, these two represent one half of the female corporate counsel interviewed who chose to discuss their roles as lawyers. ${ }^{128}$ Thus, one half of the female corporate counsel challenged by their clients over their counseling role actually made the clients' decision for them rather than continuing either the counseling role or adopting the hired gun role. The third and fourth lawyers

\section{Figure 2. The Role Taken by Lawyers in Private Practice in the Largest Centre}

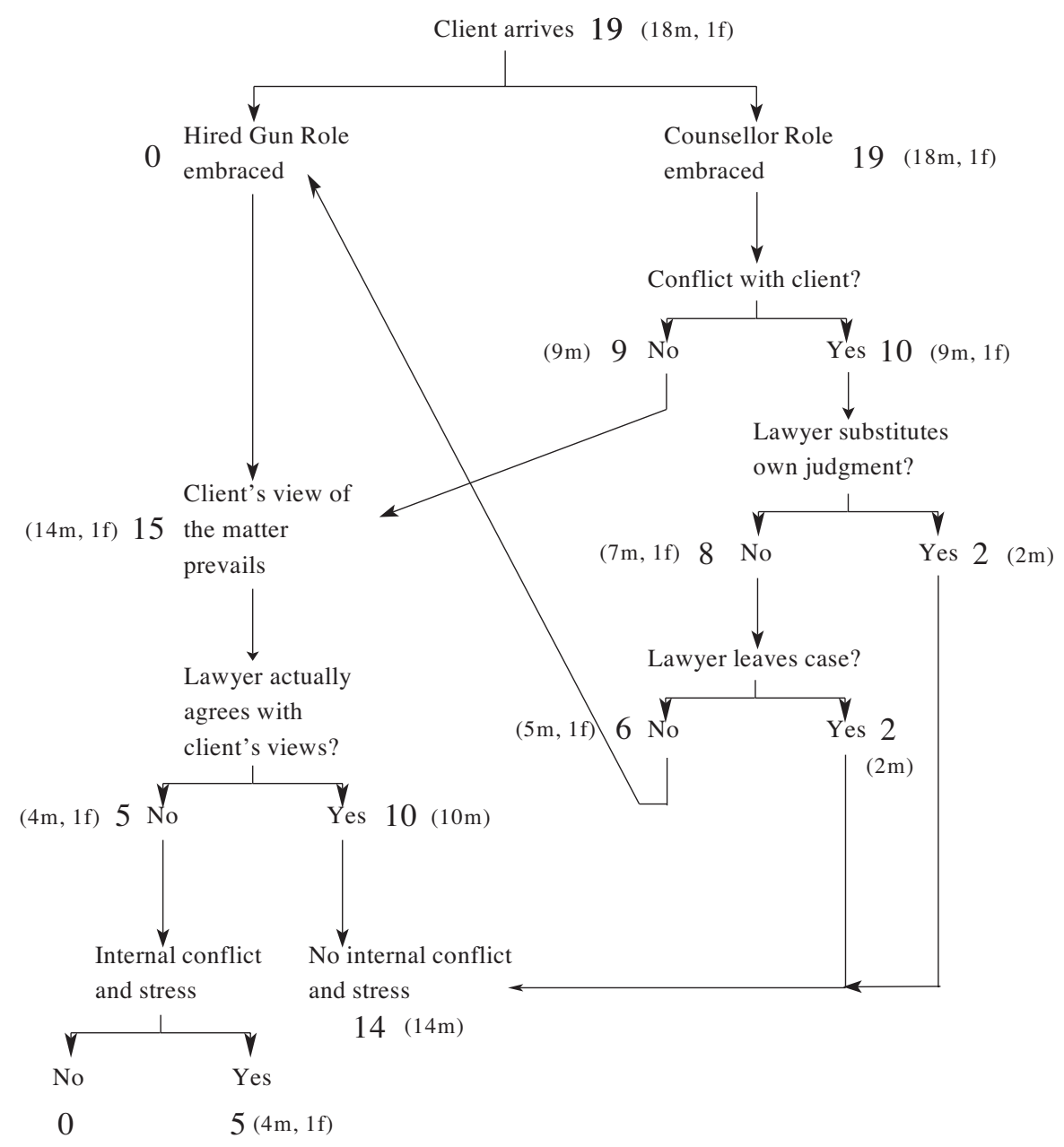


to have taken over the role of the client, rather than continuing the lawyer's role in either of its forms, were men in private practice in Toronto. ${ }^{129}$

The remaining 18 lawyers in the study who had experienced conflict with their clients, and neither withdrawn from the case nor substituted their own decisions for those of the client, chose to make the transition from mentoring role to hired gun (see again Figure 5). This group included the remaining five corporate counsel (see again Figure 1). In this role, three of the lawyers described coming to accept the client's position ( 2 private practitioners in smaller centres and one in Toronto, derived from figures shown in Figures 2 and 3 respectively, but none of the corporate counsel, refer to Figure 4) while 15 lawyers continued to disagree with the client's position, despite working within the client's instructions (see again Figure 5).

\section{Figure 3. The Role Taken by Lawyers in Private Practice}

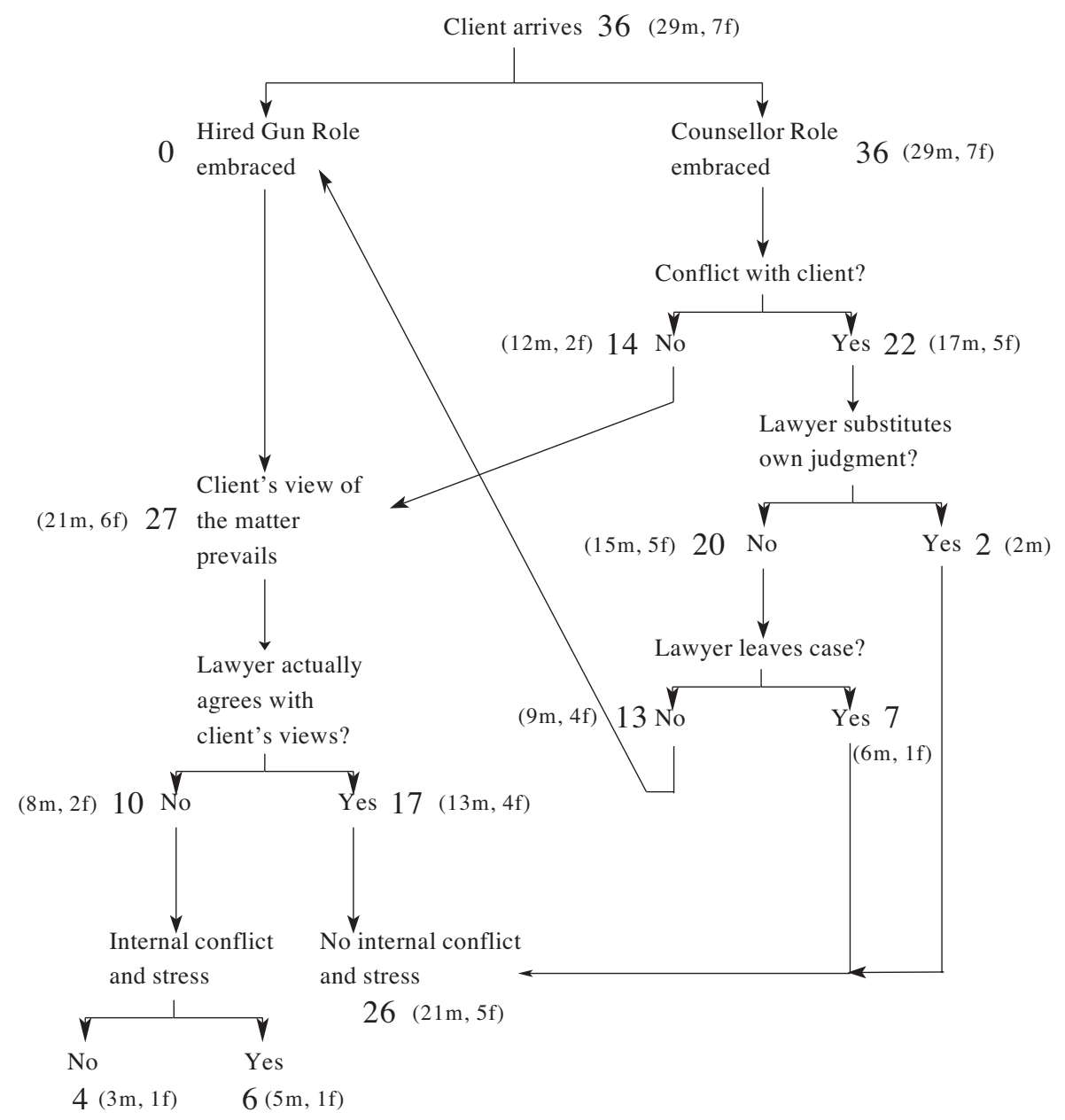




\section{Part V. Discussion}

The empirical evidence of this large scale study of the practice of lawyers across the full range of practice settings demonstrates that the issue of their role is important to many practitioners. Fully one third of the lawyers, in this representative sample of the legal profession in Ontario, when asked to describe problems in practice, raised issues involving their role. ${ }^{130}$

The data from this study also establish, however, that corporate counsel are significantly more concerned about issues of role than their counterparts in private practice: over $50 \%$ of corporate counsel describing problems in practice raised

\section{Figure 4. The Role Taken by Corporate Counsel}

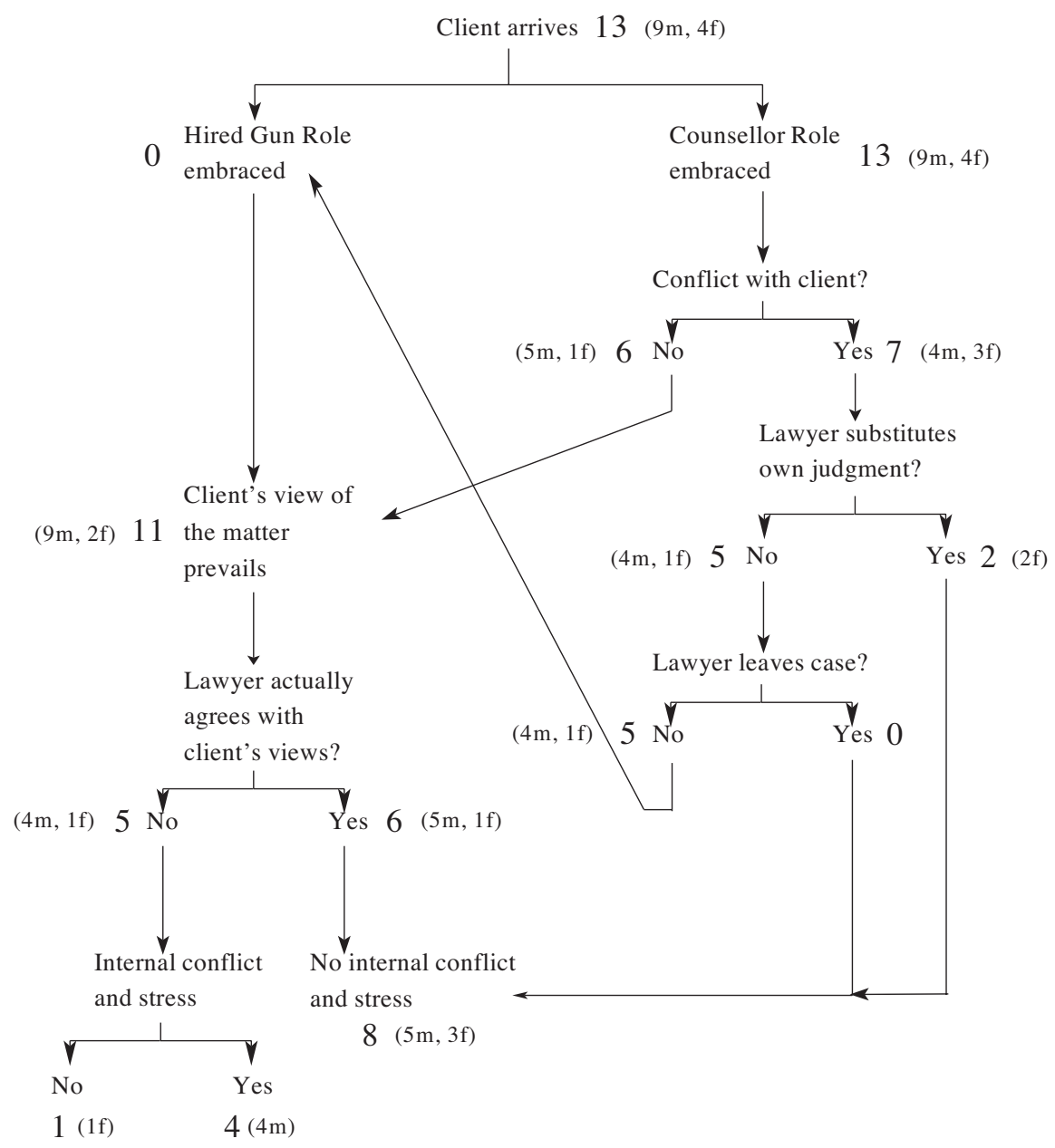


issues of role. Thus corporate counsel do appear to constitute a distinct population within the legal profession.

This study establishes further that there do exist in the practice of law two distinct approaches to the lawyers' role, identified in the literature of professionalism as the mentor or counseling model and the hired gun or mercenary model. Moreover, there are sound logical reasons for characterizing the former as an example of the care model and the latter as an example of the rights model from the moral development literature.

Given their distinctive preoccupation with role, it was expected that the corporate counsel would display a different pattern in terms of their approach to the role of

\section{Figure 5. The Role Taken by Lawyers in All Locations}

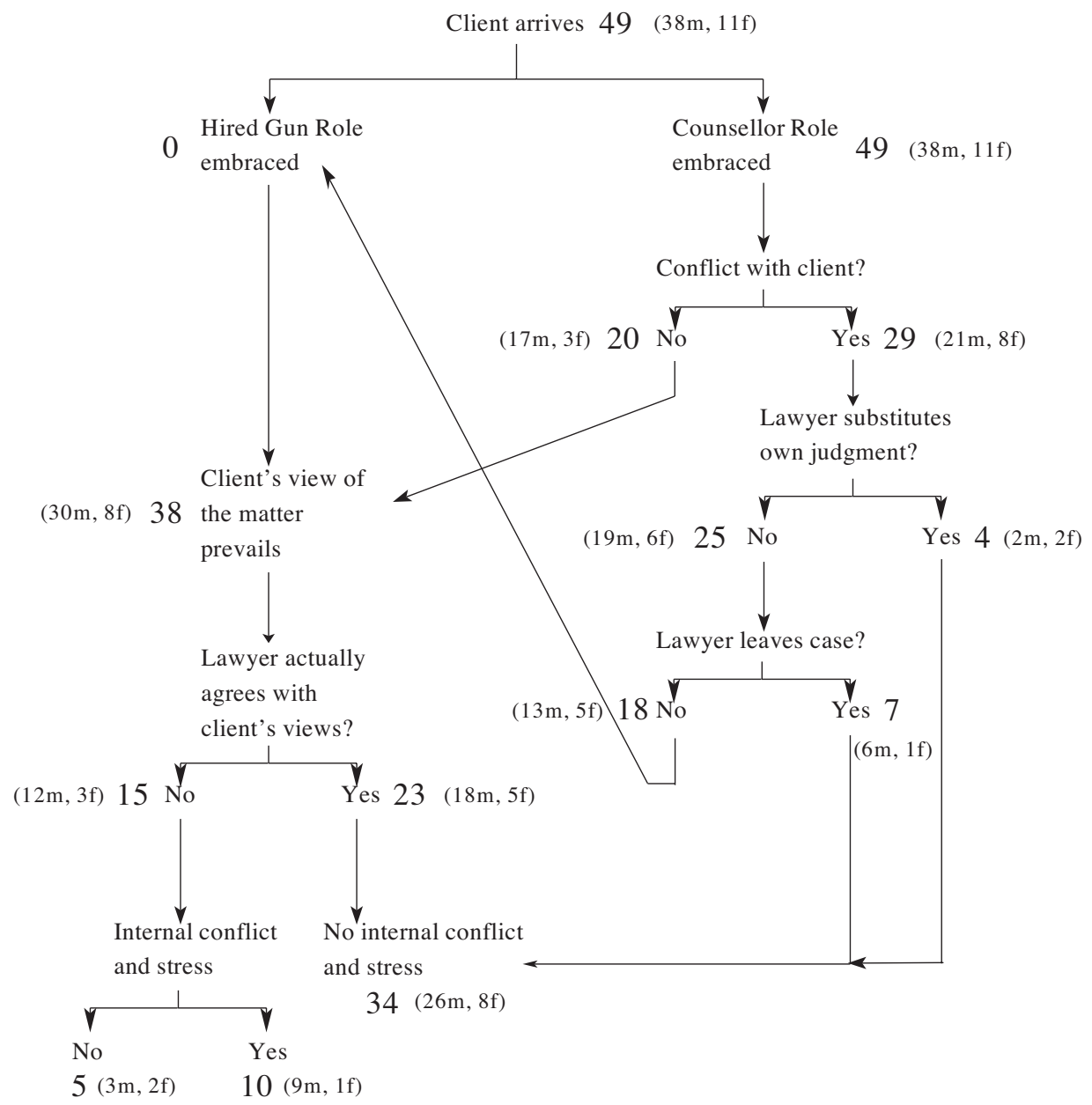


the lawyer than was exhibited by the private practitioners. However, all the practitioners, private practitioners in all sizes of centre and the corporate counsel, began with the counseling role. Faced with conflict with the client, it is true that no corporate counsel chose to withdraw from her or his case rather than abandon the counseling role, whereas seven private practitioners did $(32 \%$ of those 22 who experienced conflict with their clients ${ }^{131}$ ). However, all corporate counsel did not abandon the counseling role and adopt the hired gun role when faced with conflict: two chose to move out of the role of counsel altogether and substitute their own decisions for those of their clients. Although this was a higher percentage of lawyers than in any other category ( $29 \%$ of the seven cases of conflict with the client), and while no private practitioner in the smaller centres did this, two lawyers in private practice in Toronto ( $20 \%$ of these lawyers facing conflict with their clients) made this same choice. Finally, the corporate counsel appeared more often to suffer internal stress or conflict at the conclusion of the cases which had been problematic for them than did the private practitioners (32\% of those discussing role). However, the private practitioners from the largest centre, Toronto, were a very close second in this regard $(26 \%) .{ }^{132}$

This research also indicates, therefore, that the question of the size of centre in which the lawyer locates her or his practice has a direct bearing on that practitioner's experience of the practice of law. Only $6 \%$ of private practitioners in the smaller cities studied indicated that they experienced residual stress or internal conflict after the cases in which they had experienced problems were concluded, the lowest percentage of any of the three groups of lawyers studied. Private practitioners in Toronto were less concerned about their roles than were their counterparts in private practice elsewhere (and, as mentioned, all the private practitioners were less frequently concerned about their roles than were the corporate counsel). Those in the smaller centres more often withdrew from cases in which they experienced a conflict than occurred with their counterparts in the biggest city or the corporate counsel. No one in the smaller centres chose to substitute his or her own judgment for that of the client in a situation where conflict arose between the client's point of view and the lawyer's counseling and yet both lawyers in private practice in the largest city and corporate counsel did choose this route in a few cases.

It seems, therefore, that two aspects of the structure of the legal profession, private practice versus in-house practice and practice in the largest metropolitan area versus practice in smaller centres, ${ }^{133}$ create important variations in professional attitudes.

On the other hand, gender is not a significant factor in predicting whether lawyers will be concerned about the issue of role in connection with their problems in practice. And, despite some preliminary indications from other experimental studies that suggested otherwise, ${ }^{134}$ this study reveals no evidence in the actual practice of law that the rights perspective, or hired gun model, is identifiable particularly with male lawyers or the care perspective, or counseling model, with female practitioners. This finding is consistent with the earlier finding of this research that there was no significant difference between male and female practitioners in their resort to their professional code of conduct. Under Gilligan's theory that the female-dominated care perspective involves more consideration of the outcome of outcomes, 
a relative harms analysis and a focus on ongoing relationships, rather than the detached consideration of rule-based conflict resolution which is the hallmark of the male-dominated rights perspective, one would have expected to see more male lawyers looking to the largely rule-based ${ }^{135}$ code of professional conduct than female lawyers.

Also contrary to the expectations of the research supporting the gendering of the care and rights models in other contexts, ${ }^{136}$ in this study of the practice of law, proportionately about as many men refused to abandon the role identified with the care perspective, the counseling role, as did women lawyers. The expectation, based on the Gilligan model, had been to find more women among those steadfastly refusing to give up the mentoring role. However, while eight men actually described this experience (two substituting their own decisions and six leaving the case) whereas only three women described this refusal to give up the mentoring role (two substituting their own decisions and one leaving the case), the percentages are identical: $38 \%$ of men experiencing conflict with their clients (21) and $38 \%$ of women experiencing conflict with their clients (8) chose roles that did not require them to adopt the hired gun role (avoiding switching to the rights perspective).

With respect to the lawyers in this research who, by moving to the hired gun model, continued to follow the clients' instructions while continuing to disagree with the clients' positions, Gilligan's work led to the expectation that the majority of those who described experiencing internal stress would be women, since the men would be expected to accept the new role as dictated by the system. However, in this study, more male lawyers described continuing stress, internalized after the new hired gun role was adopted ( 9 of the 30 men who adopted the hired gun role during the cases they described (30\%) and only 1 of the 8 women who described adopting the hired gun role during the cases they discussed $(12.5 \%)$ ).

In the larger context, these findings may have several consequences. It may be that there are no legitimate gender differences between men and women, in moral perspectives or in problem-solving techniques or in development of professional roles. This would be in line with the modern feminist perspective that there is no intrinsic connection between nature and women. ${ }^{137}$ On the other hand, this study may be inconclusive on that point because it can be argued that women lawyers are not representative of women in general: perhaps by entering the profession of law, women are entering into a traditionally male world where they must behave in a masculine fashion in order to excel and this study merely gives evidence of the success of that adaptation. The research of others has shown that women who attempt to enter spheres that are traditionally masculine are required to adapt to the norms of the masculine culture and even to out-man the men. ${ }^{138}$ Certainly, in this vein, this research would bolster, for law, the argument made by Harding, in the context of women in science and technology, that increasing numbers of women will not necessarily alter the masculine character of a profession. ${ }^{139}$ This ambivalence of interpretation is prevalent in the pattern of research arising from the feminist movement: one branch argues that there are no provable differences between men and women, the other branch embraces those differences. ${ }^{140}$ 
Whatever one's perspective on the reasons behind the character of the legal profession, ${ }^{141}$ this research study, mirroring, as it does, the actual voices of the men and women practicing law in the mid-nineties, does not provide any support for the contention that the presence of women is creating a "softer voice" in the profession. In fact, in this data, the men were just as likely to question their roles as lawyers and to respond by clinging to a mentoring role, the care perspective, as the women.

These findings of this research are particularly important because they illustrate what is actually happening in the legal profession. ${ }^{142}$ They demonstrate that lawyers do rely upon perceived authority to obviate the necessity of ethical decision-making to a large extent. However, they do not often rely upon the authority of the professional code of conduct. They much more frequently rely upon the instructions of the client as the case progresses. However, reliance upon the instructions of the client, as the case progresses, is completely in harmony with the dictates of the profession in which these lawyers are working. No lawyer was found who began the relationship with the client in a hired gun mode. Although most lawyers, in the end, relinquished their decision-making to their clients', this transition from counselor to hired gun, mandated by their professional obligations, was one fraught with challenge for many lawyers. Lawyers resolved their problems in these areas, not by resort to official sources such as their code of conduct, but by resort to internal, informal sources of information such as mentors (although more lawyers in smaller firms did use external, but still informal, sources than in the other practice settings). Indeed, some lawyers in every type of practice refused to accept their client's decision as binding upon them and refused to make the transition from counselor to hired gun. (How they avoided making the transition is one of the key indicators of different attitudes to the practice of law depending upon the aspect of the structure of the profession in which the lawyer was practicing.)

This research demonstrates, therefore, that, while the majority of lawyers do follow the professionally dictated path from mentor to hired gun and thus parallel the published professional norm, the reality is that a significant proportion withdraw from cases or even substitute their own decisions for those of their clients instead of bowing to the will of their clients in cases of disagreement. While demonstrated in only a few situations, the evidence that some lawyers will substitute their own decisions for those of their clients must be a concern for the profession since it is evidence of a divergence between the individual aspirations of such lawyers and the overall goals of the legal community to represent, but not substitute for, clients. Finally, this research amply demonstrates that, although lawyers do not often refer to the formal, external documentation of their codes of ethics, lawyers are preoccupied with the constant tensions of specific solicitor-client relationships and the lawyer's overall obligations to society. 


\section{Footnotes}

1. Dr. Margaret Ann Wilkinson, called to the Ontario Bar in 1980, is a Professor, jointly appointed to the Faculty of Law and the Faculty of Information and Media Studies at the University of Western Ontario. Christa Walker first participated in this research project as a law student at the University of Western Ontario but is now called to the Bar in Ontario and, having practiced in the Toronto and Ottawa offices of Blakes, is now at the Perth office of the Australian law firm of Allens Arthur Robinson. Dr. Peter Mercer is a Professor in the Faculty of Law at the University of Western Ontario and its former Dean as well as former Vice President Administration and Corporate Counsel for the University of Western Ontario. The authors would like to thank Renata Schneider, Marcella Smit, Jonathan Mesiano-Crookston and Anna Milot for their assistance, while law students, in the preparation of this article. The authors would also like to acknowledge the funding for this paper provided by the Social Sciences and Humanities Research Council of Canada. The researchers are also deeply grateful to the 200 Ontario lawyers who participated in the pre-test and main study for this research by being interviewed and then reviewing transcripts of their interviews. The researchers are also grateful to the staff of the Law Society of Upper Canada who supported and assisted with this project and the other Ontario lawyers who assisted in the preliminary research design for the pre-test of the study.

2. See, e.g., W.G. Baker, "Structure of the Workplace or, Should we Continue to Knock the Corners off the Square Pegs or can we Change the Shape of the Holes?" (1995) 33:4 Alta. L. Rev. 821; J. Brockman, "Bias in the Legal Profession: Perceptions and Experiences" (1992) 30:3 Alta. L. Rev. 747; J. Brockman, "The Use of Self-Regulation to Curb Discrimination and Social Harassment in the Legal Profession" (1997) 35:2 Osgoode Hall L. J. 209 [Brockman, "The Use of Self-Regulation to Curb Discrimination and Social Harassment in the Legal Profession"]; F.M. Kay \& J. Hagan, "Changing Opportunities for Partnership for Men and Women Lawyers During the Transformation of the Modern Law Firm" (1994) 32 Osgoode Hall L. J. 413.

3. See, e.g., Joan Brockman, Gender in the Legal Profession: Fitting or Breaking the Mould (Vancouver: University of British Columbia Press, 2001); J. Brockman, "Gender Bias in the Legal Profession: A Survey of Members of the Law Society of British Columbia” (1992) 17 Queen's L.J. 91 [Brockman, "Gender Bias in the Legal Profession"]; J. Brockman, "Resistance by the Club to the Feminization of the Legal Profession" (1992) 7(2) C.J.L.S. 47; Law Society of British Columbia, Law Society of British Columbia Gender Bias Committee, Gender Equality in the Legal System: A Report of the Law Society of British Columbia Gender Bias Committee (Vancouver: Law Society of British Columbia, 1992); Law Society of British Columbia, Women in the Legal Profession Subcommittee, Women in the Legal Profession: A Report of the Women in the Legal Profession Subcommittee (Vancouver: Law Society of British Columbia, 1991); J. McKenzie Leiper, "It was Like Wow!: The Experience of Women Lawyers in a Profession Marked by Linear Careers" (1997) 9 (1) C.J.W.L. 115; Karen Berger Morello, The Woman Lawyer in America: 1638 to the Present: The Invisible Bar (New York: Random House, 1986).

4. See, e.g., Brockman, "Gender Bias in the Legal Profession", supra note 3; J. Brockman, "Leaving the Practice of Law: The Wherefores and the Whys" (1994) 32:1 Alta. L. Rev. 116; Canadian Bar Association, Touchstones for Change: Equality, Diversity and Accountability (Ottawa: Canadian Bar Association, 1993); F.M. Kay, N. Dautovich \& C. Marlor, Barriers and Opportunities Within Law: Women in a Changing legal Profession, A Longitudinal Survey of Ontario Lawyers 1990-1996, A Report to the Law Society of Upper Canada (Toronto: Law Society of Upper Canada, 1996); J. McKenzie Leiper, "Women Lawyers and their Working Arrangements: Time Crunch, Stress and Career Paths" (1998) 3:2 C.J.L.S. 117 [McKenzie Leiper, "Women Lawyers and their Working Arrangements"]; Sheelagh O'Donovan-Polten, The Scales of Success, Constructions of Life-Career Success of Eminent Men and Women Lawyers (Toronto: University of Toronto Press, 2001); Christopher J. Wydrzynski, Selecting and Educating Lawyers for a Changing Society: A Comparative Study of Admissions, Law School Environments and Careers of Law Graduates, Research Report (Windsor, ON: University of Windsor, 2000).

5. Peter Mercer, Margaret Ann Wilkinson \& Terra Strong, "The Practice of Ethical Precepts: Dissecting Decision-Making by Lawyers" (1996) 9:1 C.J.L.J. 141 [Mercer, Wilkinson \& Strong, "The Practice of Ethical Precepts"] at 155.

6. Various elements of preliminary analysis from the database have been published as Margaret Ann Wilkinson, Peter Mercer \& Terra Strong, "Mentor, Mercenary or Melding: An Empirical Inquiry Into the Role of the Lawyer" (1996) 28:2 Loy. U. Chicago L.J. 373 [Wilkinson, Mercer \& Strong, "Mentor, Mercenary, or Melding"]; Margaret Ann Wilkinson, Christa Walker \& Peter Mercer, "Do Codes of Ethics Actually Shape Legal Practice?" (2000) 45 McGill L.J. 645 [Wilkinson, Walker \& Mercer, "Do Codes of Ethics Actually Shape Legal Practice?"] and Margaret Ann Wilkinson, "Information Sources Used by Lawyers in Problem-Solving: an 
Empirical Exploration" (2001) 23 Library \& Information Science Research 257 [Wilkinson, "Information Sources Used by Lawyers in Problem-Solving"]. A response from the philosophical perspective to the finding presented in Wilkinson, Walker \& Mercer, "Do Codes of Ethics Actually Shape Legal Practice?" has been published by Michael Milde in 2002: see Michael Milde, "Legal Ethics: Why Aristotle Might Be Helpful" (2002) 33:1 J. Soc. Philo. 45 [Milde, "Legal Ethics"].

7. Peter Mercer and Margaret Ann Wilkinson.

8. Law Society of Upper Canada, Professional Conduct Handbook, 2nd ed. (Toronto: Law Society of Upper Canada, 1998) [Handbook]. The Handbook contains the Rules of Professional Conduct which are binding upon all member of the Law Society of Upper Canada, to which lawyers in Ontario must belong in order to practice in the province. This was the edition in force at the time these lawyers were interviewed.

9. A practice advisory service operated by the Law Society of Upper Canada. For further discussion of the role of this service in the context of this research project, see Wilkinson "Information Sources Used by Lawyers in Problem-Solving", supra note 6.

10. The first four research questions were identified as a set in Mercer, Wilkinson \& Strong, "The Practice of Ethical Precepts", supra note 5 at 142.

11. This fifth question appears in Mercer, Wilkinson \& Strong, "The Practice of Ethical Precepts", ibid. at 150 .

12. See Wilkinson, Walker \& Mercer, "Do Codes of Ethics Actually Shape Legal Practice?", supra note 6 and Wilkinson, "Information Sources Used by Lawyers in Problem-Solving", supra note 6.

13. While $16 \%$ of the respondents mentioned the Handbook in their interviews, only eleven lawyers mentioned it in connection with their problems (7\%). See Wilkinson, Walker \& Mercer, "Do Codes of Ethics Actually Shape Legal Practice?", supra note 6 at 655.

14. See Wilkinson, "Information Sources Used by Lawyers in Problem-Solving", supra note 6.

15. Ibid.

16. A total of 25 lawyers (16\%) mentioned the Handbook during their interviews, although in fourteen cases it was not in direct connection with the problems under consideration in the interview. See Wilkinson, Walker \& Mercer, "Do Codes of Ethics Actually Shape Legal Practice?", supra note 6 at 656.

17. Of the eleven lawyers who used the Handbook in relation to their problems, only seven classified their problems as involving ethics - and only six (40\%) as problems primarily focused on ethical decision-making. Of these six, only three ( $2 \%$ of the twenty-five who mentioned the Handbook at all in their interviews) found the Handbook actually resolved their problems.

18. This research found that the only transcripts that revealed evidence of ethical decision-making were three (of the eleven actually mentioning the Handbook in connection with solving their problems) - and one of these (Lawyer \#139) was a problem which did not strictly require ethical deliberation: see Wilkinson, Walker \& Mercer, "Do Codes of Ethics Actually Shape Legal Practice?", supra note 6 at 664. In the other eight cases, the Handbook appeared to obviate the necessity of ethical decision-making because the lawyers found the answers to resolve their problems in the Handbook: see Wilkinson, Walker \& Mercer, "Do Codes of Ethics Actually Shape Legal Practice?", supra note 6 at 657. On the other hand, of the eleven lawyers who mentioned the Handbook in direct connection with their problems, including both problems with an ethical component and those without, six (just under 4\%) found the Handbook actually resolved their problem - and two more found it helpful though not determinative (for a total of 5\% of the 154 lawyers whose problem-solving was studied). Three (2\%) actually commented that they had found the Handbook unhelpful in resolving their problems: see Wilkinson, Walker \& Mercer, "Do Codes of Ethics Actually Shape Legal Practice?", supra note 6 at 656.

19. See Milde, "Legal Ethics", supra note 6.

20. The full pretest, which tested both the method ultimately used for the study and the commonly used stated vignette approach, is fully reported in Mercer, Wilkinson \& Strong, "The Practice of Ethical Precepts", supra note 5.

21. As more fully discussed in Wilkinson, "Information Sources Used by Lawyers in ProblemSolving", supra note 6 at 265-68, the topics discussed by the lawyers in the study fell into two categories: problems related to the administration of law practice (client instructions, errors and omissions, conflict of interest, communications, relations with other lawyers, representing the clients, and the direct administration of the law practice (such as getting partners to agree on office renovations)) and problems relating to substantive areas of law (administrative law, immigration, corporate commercial practice, civil and criminal litigation, family law, real estate and wills and trusts). The proportion of problems raised in the study in these two categories closely paralleled the incidence of these categories of problems reported by the Lawyers Practice Advisory Service of the Law Society of Upper Canada in the same period. This then provides 
a clear answer to a question raised in the earlier preliminary report of this research project published in this journal (see Mercer, Wilkinson \& Strong, "The Practice of Ethical Precepts", supra note 5 at 148, n. 31): the problems raised by the lawyers interviewed for this study are representative of those encountered in practice.

22. See Wilkinson, Mercer \& Strong, "Mentor, Mercenary, or Melding”, supra note 6; this preliminary study was based on analysis of only the transcripts of the lawyers interviewed in this study from outside the Metropolitan area.

23. Ibid. at 410-11.

24. Mercer, Wilkinson \& Strong, "The Practice of Ethical Precepts", supra note 5 at 143.

25. Mercer, Wilkinson \& Strong, "The Practice of Ethical Precepts", supra note 5 at 143.

26. Ibid.

27. Seventeen lawyers, or $32 \%$, of the fifty-two interviews analysed from the three centers studied outside the Metropolitan center: see Wilkinson, Mercer \& Strong, "Mentor, Mercenary, or Melding", supra note 6 at 394-95 and Figure 9 at 417.

28. See the history of the Code of Professional Conduct of the Law Society of Upper Canada which was created in tandem with this research project through the efforts of then law student Darryl Robinson (see Darryl Robinson, "Ethical Evolution: The Development of the Professional Conduct Handbook of the Law Society of Upper Canada" (1995) 29 L.Soc.Gaz. 162 [Robinson, "Ethical Evolution"]).

29. See analysis of the roles in Wilkinson, Mercer \& Strong, "Mentor, Mercenary, or Melding", supra note 6 at 375-87.

30. See Wilkinson, Mercer \& Strong, "Mentor, Mercenary, or Melding", supra note 6, particularly Figure 11 at 418, where five lawyers of seventeen left the cases under discussion rather than change their roles from counselor to hired gun and accept the client's instructions even though these were not instructions in line with the counseling given and where one lawyer experienced internal conflict and stress although accepting the hired gun role.

31. The original research question, fully reproduced above, listed age and the law school alma mater of the lawyer as factors that might affect the lawyer's actions. However, as previously reported (Wilkinson, "Information Sources Used by Lawyers in Problem-Solving", supra note 6 at 272, n. 16), although data on these questions was gathered, the lawyers interviewed proved to be an almost completely homogenous group in terms of their educational backgrounds and the categorizations of experience did not prove to be sufficiently discriminatory to be analytically useful. Also, as previously reported (Wilkinson, Walker \& Mercer, "Do Codes of Ethics Actually Shape Legal Practice?", supra note 6 at 654, n. 50), the distributions of ages of both private practitioners and corporate counsel was relatively evenly split around age 40.

32. Wilkinson, "Information Sources Used by Lawyers in Problem-Solving", supra note 6 at 270.

33. Wilkinson, Walker \& Mercer, "Do Codes of Ethics Actually Shape Legal Practice?", supra note 6 at 655, n. 53: a chi-square test performed to see whether there was any significant difference between the genders in a lawyer's use of the Handbook in this research showed no significant difference.

34. Wilkinson, "Information Sources Used by Lawyers in Problem-Solving", supra note 6 at 268, 269. This variable was only meaningful with respect to the locations of the practices of the private practitioners. As mentioned below, all the corporate counsel were drawn from Toronto because that is where $88 \%$ of the population of corporate counsel studied practiced.

35. Wilkinson, Walker \& Mercer, "Do Codes of Ethics Actually Shape Legal Practice?", supra note 6 at 655, n. 53.

36. Wilkinson, "Information Sources Used by Lawyers in Problem-Solving", supra note 6 at 271.

37. Wilkinson, "Information Sources Used by Lawyers in Problem-Solving", supra note 6 at 264. Since the code is only one external source, it is not surprising that the use of the Handbook did not reflect the difference in degree of preference for external sources by size of firm that was evidence in the larger study of all information sources. See Wilkinson, Walker \& Mercer, "Do Codes of Ethics Actually Shape Legal Practice?", supra note 6 at 655, n. 53; see also Wilkinson, "Information Sources Used by Lawyers in Problem-Solving", supra note 6 at 271.

38. Wilkinson, "Information Sources Used by Lawyers in Problem-Solving", supra note 6 at 264.

39. As mentioned above, only eleven — or 7\% — of the lawyers studied mentioned the Handbook in connection with the problem-solving under discussion.

40. As discussed in the earlier report of this research in this journal (Mercer, Wilkinson \& Strong, "The Practice of Ethical Precepts", supra note 5 at 150) 88\% of corporate counsel in the Ontario Bar Association Corporate Counsel Section practiced in the Metropolitan center and therefore all of the interviews of corporate counsel in this study are drawn from there. The corporate counsel were not sampled according to the sizes of their practices, as the private practitioners were, but they were found to work in all the sizes of offices corresponding to the firm sizes of the private 
practitioners studied: 3 were the sole practitioners in their companies, 15 were practicing with between 2 and 8 other lawyers in the company, 2 worked in settings of between 9 and 30 practitioners, and 2 were in offices of more than 30 lawyers (information on the sizes of the offices in which they were working was not gathered in 3 cases).

41. The comparison between lawyers in private practice and corporate counsel in terms of their preferences for either informal or formal sources of information in problem-solving or for internal or external sources could not be made because of the small cell sizes that would have been involved in the chi square analyses: see Wilkinson, "Information Sources Used by Lawyers in Problem-Solving", supra note 6 at 268-69. Similarly, the cell sizes involved in the analyses of references to the Handbook were too small to permit chi square analyses: see Wilkinson, Walker \& Mercer, "Do Codes of Ethics Actually Shape Legal Practice?", supra note 6 at 656 (Table \#1).

42. Wilkinson, Mercer \& Strong, "Mentor, Mercenary, or Melding", supra note 6.

43. For a complete discussion of the project and methodology, see Mercer, Wilkinson \& Strong, "Practice of Ethical Precepts", supra note 5.

44. Defined as firms of over thirty practitioners, firms of between nine and thirty lawyers, and firms of between two and eight lawyers, respectively. See Mercer, Wilkinson \& Strong, "Practice of Ethical Precepts", supra note 5 at 150. As mentioned elsewhere, below, although not sampled with this variable as part of the sampling design, the corporate counsel studied represented the full spectrum of offices across these same categories.

45. The four centers represented one of the largest metropolitan centres, with a population in excess of 500,000, a large urban centre with a population of between 100,000 and 499,999, a larger medium urban centre closer to a population of 99,999 in a spectrum of between 10,000 and 99,999 , and, finally, a smaller medium urban centre, closer to the 1,000 end of the population spectrum of between 1,000 and 99,999. As demonstrated in our pre-test, reported earlier, practitioners' concerns around confidentiality made it impractical to include practitioners in centres of fewer than 1,000 in the study. See Mercer, Wilkinson \& Strong, "Practice of Ethical Precepts", supra note 5 at 149.

46. Chi square tests performed for age and gender indicated that the corporate counsel involved in the study did not differ significantly from their colleagues in private practice in the study in terms of demographics. See Wilkinson, Walker \& Mercer, "Do Codes of Ethics Actually Shape Legal Practice?", supra note 6 at 654.

47. Numbers courtesy of the Law Society of Upper Canada.

48. See Mercer, Wilkinson \& Strong, "Practice of Ethical Precepts", supra note 5 and Wilkinson, Mercer \& Strong, "Mentor, Mercenary, or Melding”, supra note 6.

49. Analysis from these data have been previously reported from several different perspectives. See Mercer, Wilkinson \& Strong, "Practice of Ethical Precepts", supra note 5; Wilkinson, Mercer \& Strong, "Mentor, Mercenary, or Melding", supra note 6; Wilkinson, "Information Sources Used by Lawyers in Problem-Solving: an Empirical Exploration", supra note 6; Wilkinson, Walker \& Mercer, "Do Codes of Ethics Actually Shape Legal Practice?", supra note 6.

50. This number includes the seventeen practitioners from outside the Metropolitan center whose interviews were analyzed in the earlier study mentioned above: Wilkinson, Mercer \& Strong, "Mentor, Mercenary, or Melding", supra note 6. In the present article, the complete findings, including the transcripts of lawyers located in the metropolitan area and the transcripts of corporate counsel lawyers, will be discussed.

51. In all earlier reports of this study, the identity of the large metropolitan centre involved in the study was not made explicit: Mercer, Wilkinson \& Strong, "Practice of Ethical Precepts", supra note 5; Wilkinson, Mercer \& Strong, "Mentor, Mercenary, or Melding", supra note 6; Wilkinson, "Information Sources Used by Lawyers in Problem-Solving: an Empirical Exploration", supra note 6; Wilkinson, Walker \& Mercer, "Do Codes of Ethics Actually Shape Legal Practice?", supra note 6 . However, in this final report of the project, that large metropolitan centre will be identified explicitly as Toronto. In the context of the structure of the legal profession in Ontario, the fact that the study includes practitioners from Toronto-and compares them with practitioners practicing outside Toronto-is important. The Law Society of Upper Canada, which is the governing body regulating lawyers in Ontario, is composed of forty Benchers duly elected by those entitled to practice law in the province. However, twenty of those elected representatives must be elected from those practicing inside Toronto and the remaining twenty are elected from those practicing in every other part of the province. See Law Society Act, R.S.O. 1990, c. L.8.

52. When all the lawyers in the study were compared, the chi square test showed no significant difference between the male and female lawyers $(\mathrm{p}=.4350, \mathrm{df}=1$, chi square $=.6094)$. When the corporate counsel were removed and the male and female private practitioners were compared, the chi square test showed no significant difference between the genders $(\mathrm{p}=.1873, \mathrm{df}=1$, chi square $=1.7385$ ). 
53. The small numbers of practitioners in several of the cells in Table $C$ meant that chi square analyses could not be performed for relevant comparisons. In the absence of these tests, it is not possible to report whether the observations being reported do or do not reveal statistically significant differences.

54. See, e.g., Jim Philips, "Beyond the Law: Lawyers and Business in Canada 1830 to 1930" in Carol Wilton, ed., Essays in the History of Canadian Law, vol. 4 (Toronto: Butterworths, 1990); Joseph Allegretti, "Have Briefcase Will Travel: An Essay on the Lawyer as Hired Gun" (1990-91) 24 Creighton L. Rev. 747; Ted Schneyer, "Some Sympathy for the Hired Gun" (1991) 41 J. Legal Educ. 11.

55. See Wilkinson, Mercer \& Strong, "Mentor, Mercenary, or Melding”, supra note 6.

56. Lawrence Kohlberg, The Philosophy of Moral Development: Moral Stages and the Idea of Justice (San Francisco, CA: Harper \& Row, 1981). According to Kohlberg's theory, a person develops morality by becoming more autonomous and less dependent on the judgement of others, until he can analyze problems in an abstract way based on universal principles of justice.

57. Carol Gilligan, In A Different Voice: Psychological Theory and Women's Development (Cambridge, MA: Harvard University Press, 1982) [Gilligan, In A Different Voice]. Gilligan's book is based on three different studies. The College Student Study explored identity and moral development in the early adult years by relating the view of self and thinking about morality to experiences of moral conflict and the making of life choices. The subjects were 25 students, selected at random from a group who had chosen as sophomores to take a course on moral and political choice. The students were interviewed as seniors in college and then five years following graduation.

The Abortion Decision Study considered the relation between experience and thought and the role of conflict in development. The subjects were 29 women, ranging in age from 15-33, diverse in ethnic background and social class, some single, others married, and a few were the mothers of preschool children. Each subject was interviewed during the first trimester of a confirmed pregnancy at a time when they were considering abortion. These women were referred to abortion clinics and pregnancy counseling services. No effort was made to select a representative sample of the clinic.

In both of these studies subjects were asked how they defined moral problems and what experiences they construed as moral conflicts in their lives rather than being given specific problems for them to resolve. The hypotheses generated by these studies concerning different modes of self were further explored and refined through the Rights and Responsibilities Study.

This study involved a sample of male and females matched for age, intelligence, education, occupation, and social class at nine points across the life cycle: 6-9 years old, 11 years old, 15 years old, 19 years old, 22 years old, 25-27 years old, 35 years old, 46 years old, and 60 years old. Data was collected on conceptions of self and morality, experiences of moral conflict and choice, and judgements of hypothetical dilemmas.

58. Since women have become a specific study group, women have been divided on whether or not gender differences actually exist. One strand of feminism argues that the alleged gender differences between women and men are simply the result of stereotypes, and asserts that there are no real differences between men and women. The other strand of feminism accepts and promotes the idea that men and women are actually different and focuses on demonstrating that the unique characteristics of women can make positive contributions to society.

59. See Debra Nails, "Social-Scientific Sexism: Gilligan's Mismeasure of Man" (1983) 50:3 Social Research 643. Nails outlines several problems with Gilligan's study. First, she argues that the presentation of the data is not representative. She compares Gilligan's account of the transcripts to the accounts of her colleagues and to the entire transcript, and argues that Gilligan chose the portions of the transcript that best illustrate the type of morality into which Gilligan felt the subject should fit. According to Nails, when the entire transcript is considered it is much less obvious that the subjects fit into one category or the other. Second, Nails attacks the interview process itself. She points out that there was no control group, no consistent test, and no rigorous scoring procedure. Also, she points out the data collected was likely influenced by the interviewer's expectations and knowledge. Finally, Nails finds fault with the assumptions underlying the study. According to Gilligan, the responses given by the subjects indicate moral maturity. However, Nails argues that it is impossible to know whether moral maturity or cognitive ability is being measured.

60. See Bill Puka, "The Liberation of Caring: A Different Voice for Carol Gilligan's Different Voice" (1990) 5:1 Hypatia 58. Puka argues that the care perspective is not so much a moral perspective as a set of coping mechanisms for dealing with sexist oppression. As well, see Catherine A. MacKinnon, "Feminist Discourse, Moral Values, and the Law-A Conversation" (1985) 34 Buff. L. Rev. 11. MacKinnon argues that the differences found by Gilligan are not a result of gender 
differences, but are a result of the fact that women have been prevented from all but nurturing methods of behaviour in society.

61. Judith Stacey, "On Resistance Ambivalence, and Feminist Theory: A Response to Carol Gilligan" (1990) 29:4 Mich. Q. Rev. 537.

62. See Jill M. Taylor, Carol Gilligan \& Amy M. Sullivan, Between a Voice and Silence: Women and Girls, Race and Relationship (Cambridge, MA: Harvard University Press, 1995); Lyn M. Brown \& Carol Gilligan, Meeting at the Crossroads: Women's Psychology and Girls Development (Cambridge, MA: Harvard University Press, 1992); Carol Gilligan, Nona P. Lyons \& Trudy J. Hanmer, eds., Making Connections: The Relational Worlds of Adolescent Girls at Emma Willard School (Cambridge, MA: Harvard University Press, 1990). Recently, Gilligan has shifted her attention from girls to adolescent boys. She has lectured on boys' emotional problems and heads a research project on boys. See the June 21, 1998 edition of Chicagoland Final Edition, by Kate Zernike (of the Boston Globe) "Feminism has Created Progress, But Man, oh man, Look what else, Woman's News" 1.

63. In 1997, Gilligan was appointed Gender Studies Chair at Harvard University; see Karen W. Arenson, "Harvard Chair will Focus a Spotlight on Gender" The New York Times (10 September 1997) A19. In addition, Gilligan was the 1997 Recipient of the Heinz Award in the Human Condition. As well, in 1996 TIME magazine named her one of the most influential Americans; see Jim Clark, “TIME 25” TIME Magazine 147:25 (June 1996) 66.

64. See Carol Gilligan, "Reply by Carol Gilligan” (1985) 11 Signs: Journal of Women in Culture and Society 324 [Gilligan, "Reply by Carol Gilligan"].

65. G. Nunner-Winkler, "Two moralities? A critical discussion of an ethic of care and responsibility versus an ethic of fights and justice" in W. Kurtines \& Gerwirtz, eds., Morality, Moral Behaviour, and Moral Development (New York: John Wiley \& Sons, 1984) 348 .

66. See Wilkinson, Mercer \& Strong, "Mentor, Mercenary, or Melding", supra note 6.

67. For further discussion of this issue, see Wilkinson, Mercer \& Strong, "Mentor, Mercenary, or Melding", ibid. This article concludes that literature presents two conflicting roles of the lawyer: the hired gun or the counselor. However, at 409, the article reveals that the law in Ontario seems to recognize the two roles as being "part of a continuum from counselor to hired gun through which the lawyer may shift in the course of serving a client".

68. For further discussion of this issue, see Wilkinson, Mercer \& Strong, "Mentor, Mercenary, or Melding”, supra note 6. As stated at 379: “... the lawyer's exclusive role is to act as an agent for the client. If a client asks for legal advice, the lawyer is clearly obligated to give such advice to the best of her knowledge and ability. After accepting the person as a client, however, the lawyer merely becomes an actor of that client." See also Robert A. Kagen \& Robert Eli Rosen, "On the Social Significance of Large Law Firm Practice" (1985) 37 Stan. L. Rev. 399.

69. Joan M. Shaughnessy, "Gilligan's Travels" (1988) 7:1 Law and Inequality 1 [Shaughnessy, "Gilligan's Travels"]. According to Shaughnessy, "the distortions created by women's status as outsiders in a male profession have made it almost impossible for women to realize and express their own sense of what it means to practice law" (19). Shaughnessy does suggest that as greater numbers of women enter the profession, these distortions will diminish. However, because of the nature of law itself, there will be limits on women's abilities to express themselves in that role. (20) Women's inclination for caregiving may be frustrated by the coercive nature of law, leading them either to feel alienated or to "learn to downplay their inclinations for caring activities". (23) Shaughnessy concludes that the ethic of care "rejects the possibility of moral governance by universal norms" (26-27). In other words, law and the ethics of care are not fully compatible.

70. Alexandra Lev-Farell, Legal Decision-Making: Does Gender Make a Difference? (1991) [unpublished paper]. Ms. Lev is currently a Partner with Berkow, Cohen LLP.

71. Kenneth Karst, "Woman's Constitution” [1984] Duke L.J. 447; Suzanna Sherry, "Civic Virtue and the Feminine Voice in Constitutional Adjudication" (1986) 72 Va. L. Rev. 543, and Carrie Menkel-Meadow, "Excluded Voices: New Voices in the Legal Profession Making New Voices in Law” (1987) 42 U. Miami L. Rev. 29.

72. Shaughnessy, "Gilligan's Travels", supra note 69 at 9-10 (footnote omitted).

73. For recent papers discussing issues of women in the practice of law, see Brockman, "The Use of Self-Regulation to Curb Discrimination and Social Harassment in the Legal Profession", supra note 2; McKenzie Leiper, "Women Lawyers and Their Working Arrangements", supra note 4.

74. Rand Jack \& Dana Crowley Jack, Moral Vision and Professional Decisions: The Changing Values of Women and Men Lawyers (Cambridge: Cambridge University Press, 1989) [Jack, Moral Vision].

75. Ibid. at $188-90$. 
76. Jack, Moral Vision, supra note 74 at 71 .

77. Ibid. at 72-85.

78. Nina J. Crimm, “A Study: Law School Students Moral Perspectives in the Context of Advocacy and Decision-Making Roles" (1994) 29:1 New Eng. L. Rev. 1 [Crimm, “A Study”].

79. The results of this study, however, may not be that meaningful. Crimm notes that there are several reasons why no differences were found: the examination context might have influenced students' responses in that they gave answers which they thought the professor was looking for; they might not have been able to relate to the victim because it was a hypothetical situation; or the process of legal education might have affected the students in that law students are taught to analyse legal issues based on rules and policies, not feelings.

80. Carla Hotel \& Joan Brockman, "Legal Ethics in the Practice of Family Law: Playing Chess While Mountain Climbing" (1997) 16 J. Bus. Ethics 809 [Hotel \& Brockman, "Legal Ethics in the Practice of Family Law"].

81. Ibid. at 814 . Note that Positions 3 and 4 are associated with the care perspective, while Positions 1 and 2 are associated with the rights perspective.

82. Jack, Moral Vision, supra note 74.

83. Because the rights model postulated by Gilligan is characterized by rights, duties and appropriate rules, if her model holds for the practice of law, the researchers would have liked to have had definitive evidence to either support or refute the hypothesis that the male lawyers are more likely to cite the Code of Professional Conduct as a source of guidance in resolving problems than would women lawyers. However, the chi-square analyses performed seeking generalizability of the findings in that regard were not significant. See Wilkinson, Walker \& Mercer, "Do Codes of Ethics Actually Shape Legal Practice?", supra note 6.

84. The second, to be introduced shortly, is the size of centre in which the lawyers are practicing.

85. "Ever since companies started recruiting in-house counsel, the [legal] profession has split into the two solitudes." Marzena Czarnecka, "Two Solitudes” Lexpert (April 2002) 66.

86. In the late nineteenth century, North American firms were changing their focus from litigation to obtaining corporate clients. The Toronto law firm of McCarthy, Osler, Hoskin, and Creelman, which existed under that name from 1882 to 1902, and is the ancestor of the modern firms of McCarthy, Tetrault and Osler, Hoskin, and Harcourt, is an example of a Canadian firm that underwent this transformation. Due to the boom in the Canadian economy at the turn of the century, firms with corporate clients did well. For example, in the early 1890s, the gross annual income of McCarthy, Osler, Hoskin, and Creelman exceeded \$100,000. In 1891-2, the firm earned $\$ 117,002.17$. Over half of this amount came from non-litigation files. Even when D'Alton McCarthy and B.B. Osler — both prominent and well-respected litigators-died, their firm survived because it had created a solid client base. For more information on this firm, see Curtis Cole, "McCarthy, Osler, Hoskin, and Creelman, 1882 to 1902" in Carol Wilton, ed., Beyond the Law: Lawyers and Business in Canada 1830 to 1930 (Toronto: The Osgoode Society, 1990) 149.

The firm belonging to E.E.A. DuVernet in Toronto is another example of a firm that owes its success in part to its shift from a traditional general practice to a specialization in corporate and commercial law. DuVernet "saw that the influence of status and wealth was shifting from the leading counsel of the time to a new élite of solicitors within the profession." John D. Honsberger, "E. E. A. DuVernet, KC: Lawyer, Capitalist, 1866 to 1915" in Carol Wilton, ed., ibid. 167 at 168

87. Richard G. Stock \& Lori D. Brazier, "Corporate Counsel and the Corridors of Power" Lexpert (April 2002) 64 [Stock \& Brazier, "Corporate Counsel and the Corridors of Power"] at 83.

88. According to Rosen, in the 1920s, inside counsel were known as "kept counsel". In the 1930s, they were referred to as "house counsel". In 1945, inside counsel began to claim the title of "corporate counsel": see Robert Eli Rosen, "The Inside Counsel Movement, Professional Judgment \& Organizational Representation" [1989] Ind. L.J. 479 [Rosen, “Inside Counsel Movement”] at 479 .

89. According to Carl D. Liggio, in "The Changing Role of Corporate Counsel" (1997) 46 Emory L.J. 1201, in the 1940s to the mid. 1970s, corporate counsel experienced "a serious decline in their stature and acceptance [because of] the emergence of the business school as a training ground and desirable discipline for senior management" (at 1201).

90. Ibid. at 1202: "by the mid-1970s, [the senior corporate counsel's] compensation had fallen to about thirty percent of the CEO's income [from sixty-five percent in the 1920s and 30s]."

91. Ibid.: "Generally, it was a one-way street between retained counsel and the corporate community-from the outside legal community into corporate legal departments. Rarely did a corporate lawyer leave to go to work in a private firm, at least not a major firm. Of course, there were incidents of this type of migration, but they were rare. In fact, there was a general perception in the 
legal community — perpetuated and expanded upon by retained counsel— that those who could not succeed at a firm were then "put" with the firm's clients in an effort to ensure a constant source of business. As a result of both the decline in compensation and the changing role, the overall quality of employed counsel deteriorated. The outside bar treated the employed corporate legal community with disdain."

92. Stock \& Brazier, "Corporate Counsel and the Corridors of Power", supra note 87 at 64-68, 70, 72, 74, 76, 78, 80-83.

93. Stock \& Brazier, "Corporate Counsel and the Corridors of Power", supra note 87 at 64-65. Note that this is actually a return to the role described above for corporate counsel pre-World War I.

94. According to Sally Gunz, in The New Corporate Counsel (Toronto: Carswell, 1991), there are three major roles that corporate counsel fulfills within the corporation: (1) performing legal tasks; (2) monitoring and managing the relationship between the corporation and whichever external law firms are being used; and (3) anticipating and preventing legal difficulties encountered by the corporation. In addition, according to Gunz, corporate counsel may also be involved in decision-making processes, depending on the size of the corporation. This picture is echoes by Rosen who describes three elements of the role (1) inside counsel engage in preventive law for their corporate clients; (2) for most legal matters, the inside counsel handles the matter internally; and (3) for matters outside the scope of their expertise, outside private counsel is brought in. Rosen, "Inside Counsel Movement", supra note 88. According to Rosen, outside counsel is retained on the recommendation of inside counsel who have become managers of corporate legal functions.

95. See Richard W. Painter, "The Moral Interdependence of Corporate Lawyers and their Clients" (1994) 67 S. Cal. L. Rev. 507.

96. The Inside Counsel Movement, fostered by the American Corporate Counsel Association, is a political movement within the profession that lobbies for increased professional status for inside counsel. For further information on the Movement: see Rosen, "Inside Counsel Movement", supra note 88.

97. Rosen equates professionalism with ethical behavior: "The virtue of lawyers subject to intrafirm processes is not based on professional interdependence. If they are ethical, their virtue lies in their exercising professional judgement to direct corporate powers." Rosen, "Inside Counsel Movement", ibid. at 553.

98. Rosen, "Inside Counsel Movement", ibid. at 525. According to Rosen, the Inside Counsel Movement lobbies for increased status and power for corporate counsel because of the broad tasks that corporate lawyers are expected to perform. Those of the Movement consider corporate lawyers to be a new breed of lawyers who are expected to manage outside counsel and practice preventive law.

99. No small urban centres were included because in the pretest the researchers found that lawyers in small towns were quite concerned that they might be identified with their interview despite the extensive precautions taken to ensure confidentiality. This concern was greater in the anecdote approach, the approach adopted for the major study. It was felt that the design of the main study should recognize and respect this concern, particularly given that, from the pretest, there appeared to be no reason to expect that small town practitioners varied from medium-sized centre, smallfirm practitioners on ethical questions. For full sampling details, see Mercer, Wilkinson \& Strong, "Practice of Ethical Precepts", supra note 5.

100. This confirms the findings of the preliminary analysis of the lawyers in private practice outside the Metropolitan area. See Wilkinson, Mercer \& Strong, "Mentor, Mercenary, or Melding", supra note 6 . The results reported in that study are here reported in the "Outside Toronto" column of Table D.

101. This Figure represents the same data as is reported in Figure 11 of the preliminary study reported in Wilkinson, Mercer \& Strong, "Mentor, Mercenary, or Melding", ibid. at 418, although the diagram has been drawn slightly differently in order to show direct comparison in this article with the findings regarding the corporate counsel and lawyers in private practice within the Metropolitan area, Toronto. Specifically, although no lawyers in the smaller centres reported this, a branch has been added to indicate the possibility that the lawyer substitutes her or his own judgement for that of the client.

102. Lawyer F (corresponding with the identification in Wilkinson, Mercer \& Strong, "Mentor, Mercenary, or Melding", supra note 6).

103. Shown on the right hand branch of the first branching in Figures 1, 2 and 4.

104. The elements of row 5 of Table $D$ are shown on the right hand branch of the second branching in Figures 1, 2 and 4.

105. And, correspondingly, the left hand branch of the third branching of Figures 1,2 and 4 (the 3rd branching appears toward the middle of the right hand side of each of these figures).

106. Lawyer No. 118. 
107. This is illustrated in the right hand branch of the fourth decision branching in Figure 4: compare with the private practitioners depicted in Figures 1 and 2.

108. Toward the very end of the interview with Lawyer 129 , for example, the Interviewer gave a prompt which might have led to such a discussion but instead led to a different, very interesting exchange about the identity of the corporate client:

Interviewer: But the client is also your employer.

Really, it is. That's right. The question is who's your client? If the client's the company, but the company only exists [as a] legal fiction. I look at the clients as the physical people who are trying to represent the company's interests. When I talk about risks for the company, I am keeping in mind the obligation of the company to its shareholders. ... So when you are [asking] who's your client, you are always engaged in a difficult analysis. I can't view the individual who is sending me something, a problem to look at or a situation they want to have advice upon, that individual's not the client. Yet you deal with these people all the time and there's not really a conflict, but a balance to be struck all the time between the fact that you're trying to serve that person and help them get their job done, but underlying it is serving the larger ... corporation. ... where I'm advising on things like dismissals, the company's reducing work force ... I'm always thinking, what's the balance between the company paying the minimum [and] what's fair to take into consideration for that particular employee. ... So I think either explicitly or implicitly you're balancing these various interests. I mean, if somebody asks me "what's our obligation to disclose something?", I'm thinking what's our obligation to our shareholder, what's our obligation to the securities legislation, what should we be advising our directors to do? It's not clear cut. You're not an advocate in the pure sense.

In one other case, the lawyer raised the question indirectly, at the tail end of the interview, when discussing his current role as opposed to a previously held position:

So [the fellow employee of the former corporate employer] was putting me in this very awkward position of either I do it for him because he's right here and I might lose my job if I don't, or I you know, offend him, maybe ultimately lose my job, but answer to who I actually reported to [rather than the employee requesting]. ... And I was a first year lawyer, and it was an awful conundrum ... I don't consider that a real decision except as to a personal decision ... I chose to handle it like the typical first year scared lawyer, and I found my immediate supervisor who was a lawyer. [Lawyer No.118, in an aside]

109. As is evident from the following transcript, the threat to withdraw from a file is not made lightly by counsel in private practice and is made in full knowledge that, while it might not mean dismissal as is perhaps a possibility in the case of the corporate counsel, it can have direct financial consequences for the firm and, indirectly, for the future of the lawyer involved:

This particular client wanted me to do something that I felt was improper and I expressed it to him, and he was quite upset. In fact, he was yelling at me and telling me he was disappointed. ... But I told him I just couldn't do that and maybe he could find some other lawyer to do what he had asked me to do.... And again he was quite upset, and when he hung up the phone I went to the senior partner and I said "I think I have just blown the big client" and explained to him the situation. And, fortunately for me, the senior partner said, "You have done the right thing, and we'll see what the outcome is." And believe me, I lost sleep over it. This is a substantial client; this is somebody who demands things to happen and usually gets them done. [Lawyer A]

110. This change in the lawyers' roles is illustrated in Figures 1 through 5 by the diagonal reaching up from the lower right hand side of each figure, beginning at the left hand branch of the 4th decision juncture and ending back at the upper left of each figure where the "Hired Gun Role embraced" is labeled.

111. The lawyers in this position are shown in Figures 1 to 5 on the left branch of the 2nd branch, "Conflict with Client?" then moving in a downward diagonal across to the left hand side of each figure, flowing into the number shown for "Client's view of the matter prevails".

112. These two sets of lawyers are shown on the right and left branches, respectively, of the first branch in the lower left of each of Figures 1 to 5 .

113. It may be noted that although none of these lawyers indicated any residual conflict or stress over the outcome of these cases during the interviews, these are all cases raised by these lawyers as recent problems in their practice which they wished to describe when asked by the interviewers for this research to choose a significant recent problem in their practices on which to base the interview. Thus, although there was no reported stress or conflict involved in these outcomes, developing the solutions to these problems had been involved enough to flag them to the participants as worthy of discussion in this research. Lawyer No.118, for example, who has been quoted above, commented as follows: 
But I mean I can't say that anyone sat here overnight worrying about it. ...

Interviewer: Were you able to discuss it with anybody?

Actually that was why I picked that particular situation [to discuss in the interview], No. ... It was quite a strange day. I had one other person that I was working with ... And she was relying on me completely from the perspective of what are we allowed to do and what are we not allowed to do.... At the end of the day, I'm more senior than she is in position, so I have to make the decision. ... And so I made an executive decision and went with it.

Lawyer F, quoted above, after describing the counseling role in a custody case, commented as follows:

Interviewer: ... what exactly was the difficult decision for you?

Whether or not I was making the right decision in trying to educate my client about what she was looking at in the future; should she pursue the instructions which she originally gave me? That was my hard decision to make, do I accept it and just say blindly, "let's go ahead and litigate this", or do I try and inform her? And my decision was to inform her, at least then it would be an informed decision.

114. See Table D 13th row and the right hand branch of the last branching on the lower left hand side of Figures 1 to 5 .

115. See left hand side of Figure 5 "Client's view of the matter prevails."

116. See top value in Figure 5, labeled "Client arrives."

117. See left hand side of Figure 4 "Client's view of the matter prevails."

118. See right hand side of Figure 4 at third branching and fourth branching respectively.

119. See left hand side of Figure 2 "Client's view of the matter prevails."

120. See right hand side of Figure 2 at third branching and fourth branching respectively.

121. See left hand side of Figure 1 "Client's view of the matter prevails."

122. See right hand side of Figure 1 at third branching and fourth branching respectively.

123. Lawyer No.129

124. Lawyer No.86

125. See again Table D 13th row.

126. See again toward the lower right side of Figure 5.

127. See again Figure 4, right side.

128. See again top of Figure 4.

129. See again Figure 3, right side.

130. This issue was the largest single common thread found by the researchers in the 154 transcripts.

131. However, it must be noted that there was a split in this regard between private practitioners in Toronto, who only withdrew from cases where there was conflict with the client in $20 \%$ of cases, whereas in the smaller centres, conflict with the client led the private practitioners to withdraw in $42 \%$ of cases.

132. Indeed, it will be recalled that in fact the corporate counsel were from the same large city, so perhaps this is a strong validation of the anecdotal evidence that practice in smaller centres is less stressful—with only $6 \%$ of practitioners from the smaller centres ultimately giving evidence of internal stress or conflict.

133. Whereas analyses in this research of the sources of information used by lawyers in problem solving and specifically the use of the code of conduct by lawyers demonstrated that differences between private practitioners depending upon the size of firm in which they practiced were not significant.

134. As discussed above, Jack, Moral Vision, supra note 74 and Brockman, "The Use of SelfRegulation to Curb Discrimination and Social Harassment in the Legal Profession", supra note 2 were studies based upon hypotheticals that suggested differences would be found whereas Crimm, "A Study", supra note 78 had found no differences.

135. See Robinson, "Ethical Evolution", supra note 28.

136. See Shaughnessy, "Gilligan's Travels", supra note 69 and Gilligan, "Reply by Carol Gilligan", supra note 64.

137. See Rosemarie Putman, Feminist Thought: A More Comprehensive Introduction, 2nd ed. (Boulder, CO: Westview Press, 1998).

138. See Frances K. Conley \& Delese Wear, Privilege in the Medical Academy: A Feminist Examines Gender, Race and Power (New York: Teachers College, Columbia University, 1997); Frances K. Conley, Walking Out on the Boys (New York: Farrar, Strauss, and Giroux, 1998).

139. See Sandra Harding, The Science Question in Feminism (Ithaca, NY: Cornell University Press, 1986) at 21.

140. See Shaughnessy, “Gilligan's Travels”, supra note 69 at 9. 
141. See C.J. Wydrzynski, L. Chartrand, M. Cormier, D. Eansor, K. Hildebrandt, H.L. O’Brien and D.J. Blonde, Selecting and Educating Lawyers for a Changing Society: A Comparative Study of Admissions, Law School Environments and Careers of Law Graduates [Report to Funding Agencies] (n.p., March 2000). See also the subsequent publication from the report: Larry N. Chartrand, Dolores J. Blonde, Michael Cormier, Kai Hildebrandt, Christopher Wydrzynski \& Edward J. Czilli, "Law Students, Law Schools, and their Graduates," (2001) 20 Windsor Yearbook of Access to Justice 211. The study examined five law schools (University of Windsor, University of Western Ontario, Université de Montreal, Dalhousie University and University of Alberta) roughly during the period 1992-1995, surveying students and alumni. This large study focused on variation between schools in their admissions policies and the effects of the changing composition of law students (in terms of such factors as age, gender and race) on attitudes toward such matters as legal education, careers and law practice. The study focused on the effects of increased multiculturalism in the legal profession as being at least as important as the effects of the increased numbers of women in the profession.

142. As opposed to the previous studies canvassed above in relation to both ethics and gender in the legal profession which relied upon hypothetical situations in their research methodologies. On gender alone, see, e.g., the Rights and Responsibilities Study in Gilligan, In A Different Voice, supra note 57. On legal ethics and gender, see, e.g., Crimm, "A Study", supra note 78 and Hotel \& Brockman, "Legal Ethics in the Practice of Family Law", supra note 80. 
